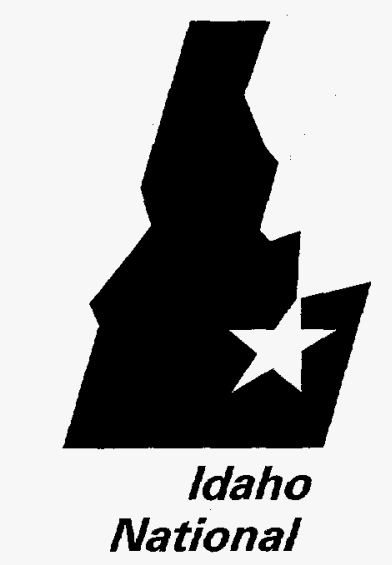

Engineering Laboratory

\section{Demonstration of an Optimized TRUEX Flowsheet for Partitioning of Actinides from Actual ICPP Sodium- Bearing Waste Using Centrifugal Contactors in a Shielded Cell Facility}

J. D. Law

K. N. Brewer

R. S. Herbst

T. A. Todd

L. G. Olson

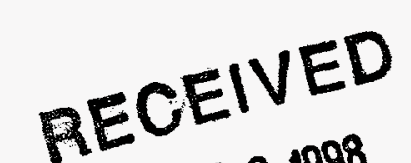

RECEIVED

MAR 131998

O STI 


\section{DISCLAIMER}

This report was prepared as an account of work sponsored by an agency of the United States Government. Neither the United States Government nor any agency thereot. nor any of their employees, makes any warranty, express or implied. of assumes any legal liability or responsibility for the accuracy. completeness, or usefulness of any information, apparatus, product or process disclosed, of represents that its use would not infringe privately owned nights. References herein to any specific commercial product, process, or service by trade name, trademark, manutacturer, of otherwise. does not necessarily constitute or imply its endorsement, recommendation, or favoring by the United States Government or any agency thereof. The views and opinions of authors expressed herein do not necessarity state or reflect those of the United States Government or any agency thereof. 
INEEL/EXT-98-00004

\title{
Demonstration of an Optimized TRUEX Flowsheet for Partitioning of Actinides from Actual ICPP Sodium- Bearing Waste Using Centrifugal Contactors in a Shielded Cell Facility
}

\author{
J. D. Law \\ K. N. Brewer \\ R. S. Herbst \\ T. A. Todd \\ L. G. Olson
}

Published January 1998

Idaho National Engineering and Environmental Laboratory

High Level Waste Program

Lockheed Martin Idaho Technologies Company

Idaho Falls, Idaho 83415

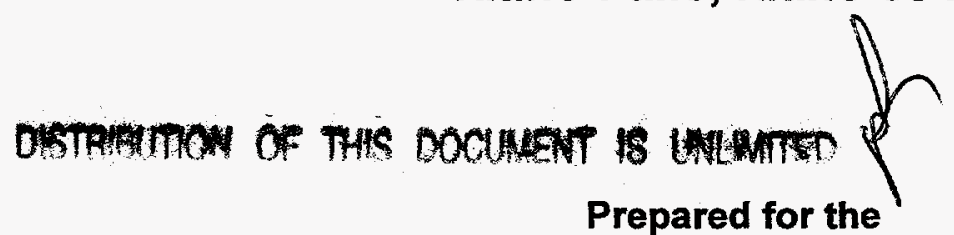

Wh ma

U.S. Department of Energy

Assistant Secretary for

Environmental Management

Under DOE Idaho Operations Office

Contract DE-AC07-94ID13223 


\section{DISCLAIMER}

Portions of this document may be illegible electronic image products. Images are produced from the best available original document. 


\section{ABSTRACT}

The TRUEX process is being evaluated at the Idaho Chemical Processing Plant (ICPP) for the separation of the actinides from acidic radioactive wastes stored at the ICPP. These efforts have culminated in recent demonstrations of the TRUEX process with actual tank waste. The first demonstration was performed in 1996 using 24 stages of 2-cm diameter centrifugal contactors and waste from tank WM-183. Based on the results of this flowsheet demonstration, the flowsheet was optimized and a second flowsheet demonstration was performed. This test also was performed using 2-cm diameter centrifugal contactors and waste from tank WM-183. However the total number of contactor stages was reduced from 24 to 20 . Also, the concentration of HEDPA in the strip solution was reduced from $0.04 M$ to $0.01 M$ in order to minimize the amount of phosphate in the HLW fraction, which would be immobilized into a glass waste form. This flowsheet demonstration was performed using centrifugal contactors installed in the shielded hot cell at the ICPP Remote Analytical Laboratory. The flowsheet tested consisted of six extraction stages, four scrub stages, six strip stages, two solvent wash stages, and two acid rinse stages.

An overall removal efficiency of $99.79 \%$ was obtained for the actinides. As a result, the activity of the actinides was reduced from $540 \mathrm{nCi} / \mathrm{g}$ in the feed to $0.90 \mathrm{nCi} / \mathrm{g}$ in the aqueous raffinate, which is well below the NRC Class A $\mathrm{LLW}$ requirement of $10 \mathrm{nCi} / \mathrm{g}$ for non-TRU waste. Removal efficiencies of 99.84\%, 99.97\%, 99.97\%, 99.85\%, and 99.76\% were obtained for ${ }^{241} \mathrm{Am},{ }^{238} \mathrm{Pu}$, ${ }^{239} \mathrm{Pu},{ }^{235} \mathrm{U}$, and ${ }^{238} \mathrm{U}$, respectively. Iron was effectively scrubbed from the TRUEX solvent, resulting in only $0.7 \%$ of the $\mathrm{Fe}$ exiting in the strip product. Mercury was extracted by the TRUEX solvent (74\%) and stripped from the solvent in the $0.25 \mathrm{MNa}_{2} \mathrm{CO}_{3}$ wash section. Only $0.45 \%$ of the $\mathrm{Hg}$ exited with the high-activity waste strip product. The $0.01 \mathrm{M}$ HEDPA strip section backextracted $99.4 \%$ of the actinide activity from the TRUEX solvent. However, poor material balances for the actinides, combined with the slight amount of precipitate observed when the stage 11 (strip product) solution was reequilibrated after shutdown, indicate that a precipitate formed in the strip section during operation. It is expected that this precipitate can be eliminated with a small adjustment of the HEDPA concentration and/or flowrate in the strip section. 



\section{ACKNOWLEDGEMENTS}

The authors would like to acknowledge Troy Garn, Carl Lundholm, Rich Tillotson, and Earlen Wade for their assistance with laboratory testing, operation of the centrifugal contactors, chemical makeup, and sample preparations.

Many thanks to Brian Storms, Doug Thompson, Ron Stone, and Dean Goodwin of the Radiochemical Analysis Group, Jeff Laug, Duane Lundholm, and Dennis Nielsen of the Spectrochemical Analysis Group, and the RAL analysts for the efficient, expedient sample analysis.

Without the work and dedication of these people, this test could not have proceeded. 


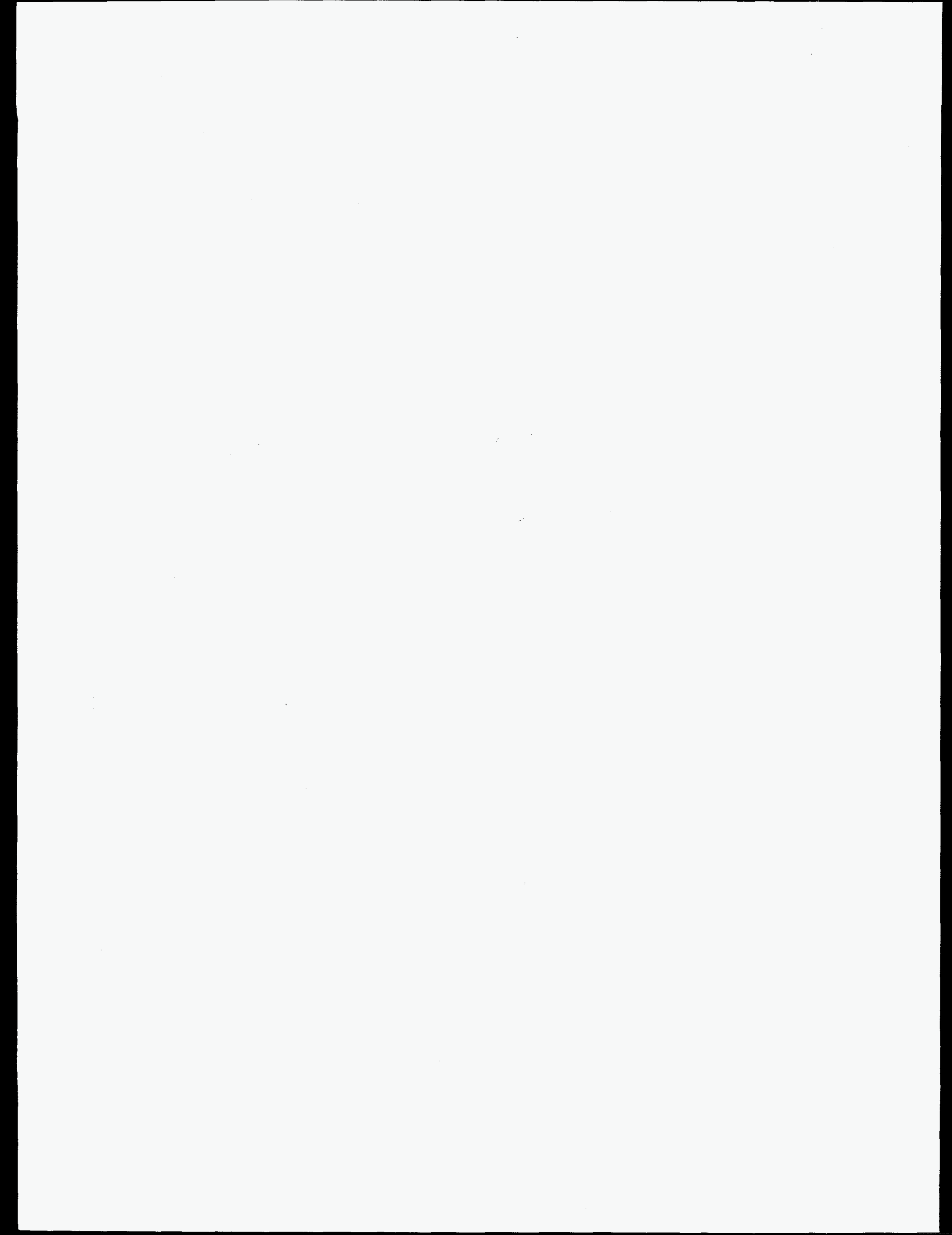




\section{CONTENTS}

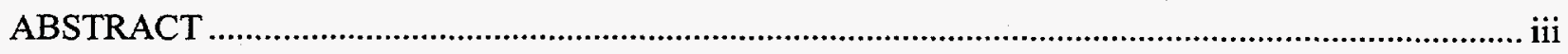

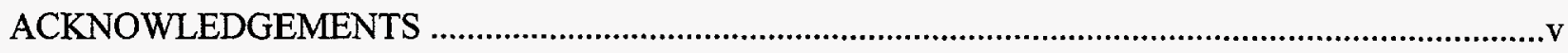

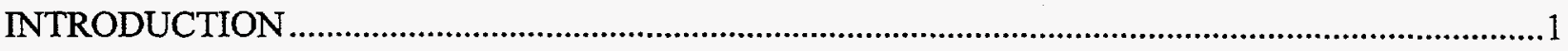

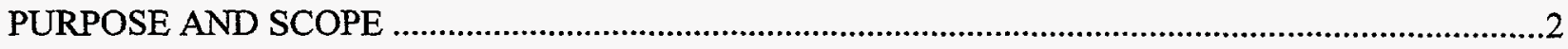

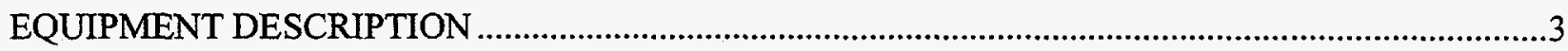

METHODOLOGY/EXPERIMENTAL PROCEDURE ...........................................................................

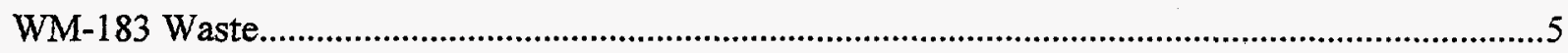

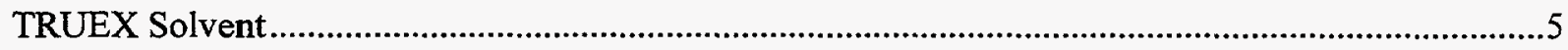

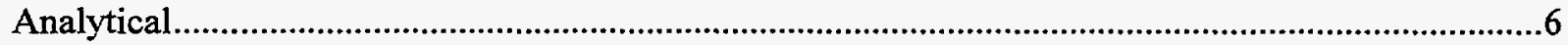

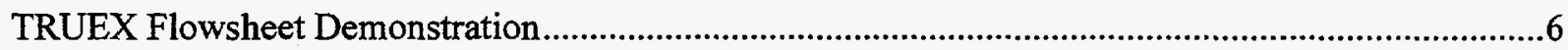

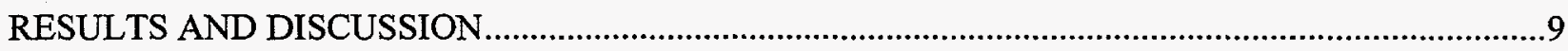

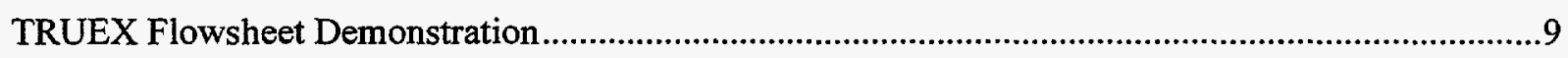

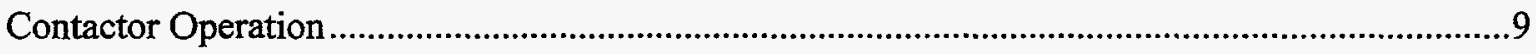

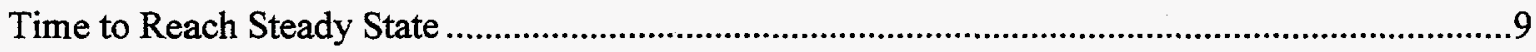

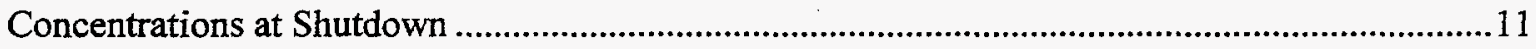

Comparison With Results Obtained Using SBW Simulant .......................................................15

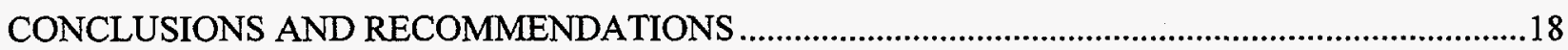

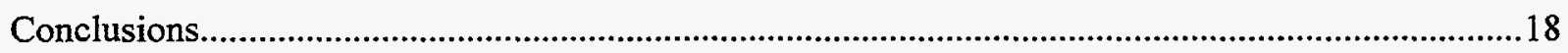

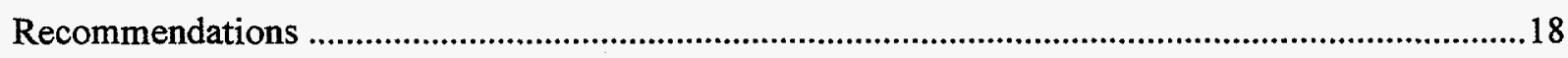

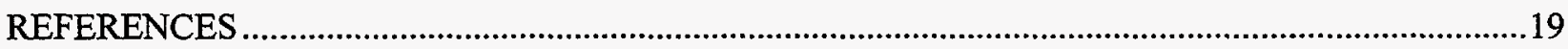

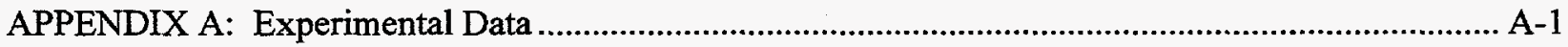




\section{TABLES}

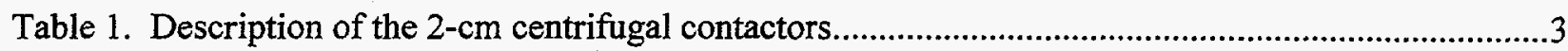

Table 2. WM-183 waste and average SBW tank compositions..........................................................

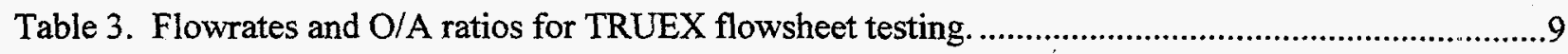

Table 4. Percentage of component in each of the effluent streams for TRUEX flowsheet testing. ..........13

Table 5. Gross alpha, ${ }^{241} \mathrm{Am},{ }^{238} \mathrm{Pu},{ }^{239} \mathrm{Pu},{ }^{235} \mathrm{U}$, and ${ }^{238} \mathrm{U}$ distribution coefficients for TRUEX flowsheet testing.

Table 6. $\mathrm{H}^{\dagger}, \mathrm{Fe}$, and $\mathrm{Hg}$ distribution coefficients for TRUEX flowsheet testing. ................................14

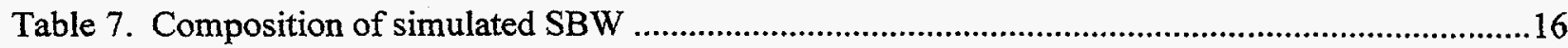

Table 8. Comparison of results obtained from flowsheet testing with simulant and actual waste. 17

\section{FIGURES}

Figure 1. 2-cm diameter centrifugal contactors installed in the RAL shielded cell . .4

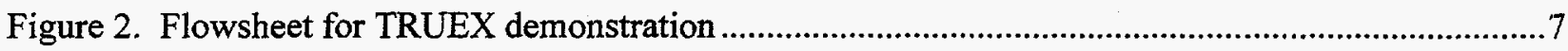

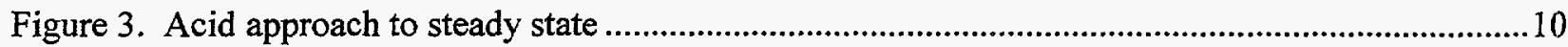

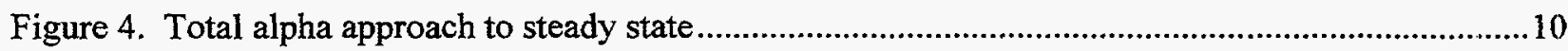

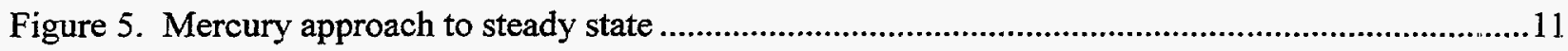

Figure 6. TRUEX flowsheet test concentrations at shutdown. .........................................................12 


\title{
Demonstration of an Optimized TRUEX Flowsheet for Partitioning of Actinides from Actual ICPP Sodium- Bearing Waste Using Centrifugal Contactors in a Shielded Cell Facility
}

\author{
INTRODUCTION
}

The Idaho Chemical Processing Plant (ICPP), located at the Idaho National Engineering and Environmental Laboratory (INEEL), formerly reprocessed spent nuclear fuel to recover fissionable uranium. The radioactive raffinates from the solvent extraction uranium recovery processes were converted to granular solids (calcine) in a high temperature fluidized bed. During the course of reprocessing, a secondary waste stream, liquid sodium-bearing waste (SBW), was also generated primarily from equipment decontamination between campaigns and solvent wash activities. This SBW cannot be directly calcined due to the high sodium content and has historically been blended with reprocessing raffinates or non-radioactive aluminum nitrate prior to calcination. Fuel reprocessing activities are no longer being performed at the ICPP, thereby eliminating the option of waste blending to deplete the SBW inventory. Currently, approximately 5.7 million liters of liquid SBW are temporarily stored at the ICPP in large underground stainless-steel tanks.

The United States Environmental Protection Agency and the Idaho Department of Health and Welfare filed a Notice of Noncompliance in 1992 contending some of the underground waste storage tanks do not meet secondary containment requirements as set forth in Title 40, Part 265.13 of the Code of Federal Regulations. As part of a 1995 agreement between the State of Idaho, the Department of Energy, and the Department of Navy, the SBW must be removed from the tanks by 2012.

Treatment of the SBW inventories by partitioning the radionuclides and immobilizing the resulting high-activity and low-activity waste streams has been under evaluation for the last several years. A recent peer review identified the most promising radionuclide separation technologies for evaluation. ${ }^{1}$ The Transuranic Extraction (TRUEX) process, developed by Horwitz and Schulz, ${ }^{2}$ was identified as a primary candidate for separation of the actinides from ICPP SBW. The Strontium Extraction (SREX) process, developed by Horwitz, ${ }^{3-5}$ was identified as a primary candidate for separation of ${ }^{90} \mathrm{Sr}$ from ICPP SBW.

A major emphasis at the ICPP has been directed toward evaluating actinide separation technologies for SBW using the TRUEX process. The active extractant used in the TRUEX process solvent is octyl(phenyl)-N,N-diisobutylcarbamoylmethylphosphine oxide (CMPO). Tributylphosphate (TBP) is added to the solvent as a phase modifier to prevent third phase formation and a paraffinic hydrocarbon is used as a diluent. The TRUEX process has been effectively demonstrated to remove actinides from actual SBW using 2-cm diameter centrifugal contactors to well below the $10 \mathrm{nCi} / \mathrm{g} \mathrm{NRC} \mathrm{Class} \mathrm{A} \mathrm{low-}$ level transuranic waste requirements. ${ }^{6}$ As a result of this testing, the TRUEX flowsheet was optimized by (1) reducing the total number of stages from 24 to 20, and (2) reducing the concentration of HEDPA in the strip feed from $0.04 M$ to $0.01 M$. This report describes the results of testing the modified TRUEX flowsheet with actual SBW (from tank WM-183) using 2-cm diameter centrifugal contactors in a shielded cell facility. 


\section{PURPOSE AND SCOPE}

The purpose of this study was to demonstrate an optimized TRUEX flowsheet which will effectively extract and strip the actinides from actual ICPP SBW under continuous countercurrent conditions. Installation of the 2-cm centrifugal contactors in the ICPP Remote Analytical Laboratory (RAL) shielded hot cell allowed the use of actual SBW in testing of the TRUEX process. Consequently, the scope of this study was to evaluate the optimized TRUEX flowsheet using actual ICPP tank waste. The behavior of the actinides and the non-radioactive components was evaluated for the flowsheet. Specifically, the ability to achieve the NRC Class A LLW criteria of $10 \mathrm{nCi} / \mathrm{g}$ for the actinides was evaluated. Also, the effect of reducing the HEDPA concentration of the strip from $0.04 M$ to $0.01 M$ was evaluated. 


\section{EQUIPMENT DESCRIPTION}

Flowsheet testing was performed using 2-cm diameter centrifugal contactors installed in the CPP684 RAL shielded hot cell. The 2-cm centrifugal contactors, as shown in Figure 1, consist of 24 stages of $2-\mathrm{cm}$ diameter centrifugal contactors, feed and receiving vessels, feed pumps, and an air purge system for the contactor bearings. The aqueous and organic feed pumps and feed vessels were located inside the shielded cell. The remaining feed pumps and feed vessels were located outside the cell. All of the feed pump controllers were located outside the cell. Non-radioactive solutions used for the flowsheet testing were pumped to the centrifugal contactors through penetrations in the cell wall.

The centrifugal contactors were designed and fabricated by Argonne National Laboratory (ANL). The centrifugal contactors were designed specifically for operation of the TRUEX process with ICPP SBW. The contactors were modified at the ICPP for remote installation and operation in the RAL hot cell. Specifically, a modified support structure was fabricated for the contactors. This support structure is portable to allow the contactors to be moved out of the way when not in operation, contains leveling screws to adjust for unevenness in the cell floor, and can be disassembled into three sections. It was necessary to design the support structure for disassembly and reassembly so that the structure would fit through the $12 \mathrm{in.} \mathrm{by} 22 \mathrm{in}$. glove box access port into the cell and be assembled remotely. The centrifugal contactors were also installed through the access port in groups of four and assembled on the support structure remotely. Lifting bails were installed on each contactor to facilitate remote replacement or inspection of any motor/rotor assemblies. A description of the centrifugal contactors is provided in Table 1.

Solution was fed to the contactors using valveless metering pumps. Surge lines, consisting of 4inch sections of 1-inch stainless steel tubing, were placed on the outlet of the pumps to dampen the surging flow. Because of the difficulty associated with remote installation, surge lines were not installed for the aqueous and organic feed pumps located in cell. Flowrates were adjusted by controlling the pump speed using a ten-turn potentiometer or by manually adjusting the piston stroke length.

Clear, flexible Teflon ${ }^{\circledR}$ or Teflon ${ }^{\circledR}$ lined Tygon ${ }^{\circledR}$ tubing was used for inlet and outlet connections to the feed and receiving vessels. The feed lines were $1 / 8$ in. o.d. tubing and the product lines were $3 / 8$ in. o.d. tubing.

Table 1. Description of the $2-\mathrm{cm}$ centrifugal contactors.

\begin{tabular}{ll} 
Size & $2-\mathrm{cm}$ rotor diameter \\
Motor & 115 Volt, $60 \mathrm{~Hz}$ Bodine Model 710 \\
RPM & $3,600 \mathrm{rpm}$ (not adjustable) \\
Material of construction & $304 \mathrm{~L}$ stainless steel \\
Inlet and outlet ports & $3 / 8$ in. o.d. tubing \\
Configuration & $\begin{array}{l}\text { Single stage units which can be configured as } \\
\text { desired. Stages are connected using U- tubes. }\end{array}$ \\
\hline
\end{tabular}




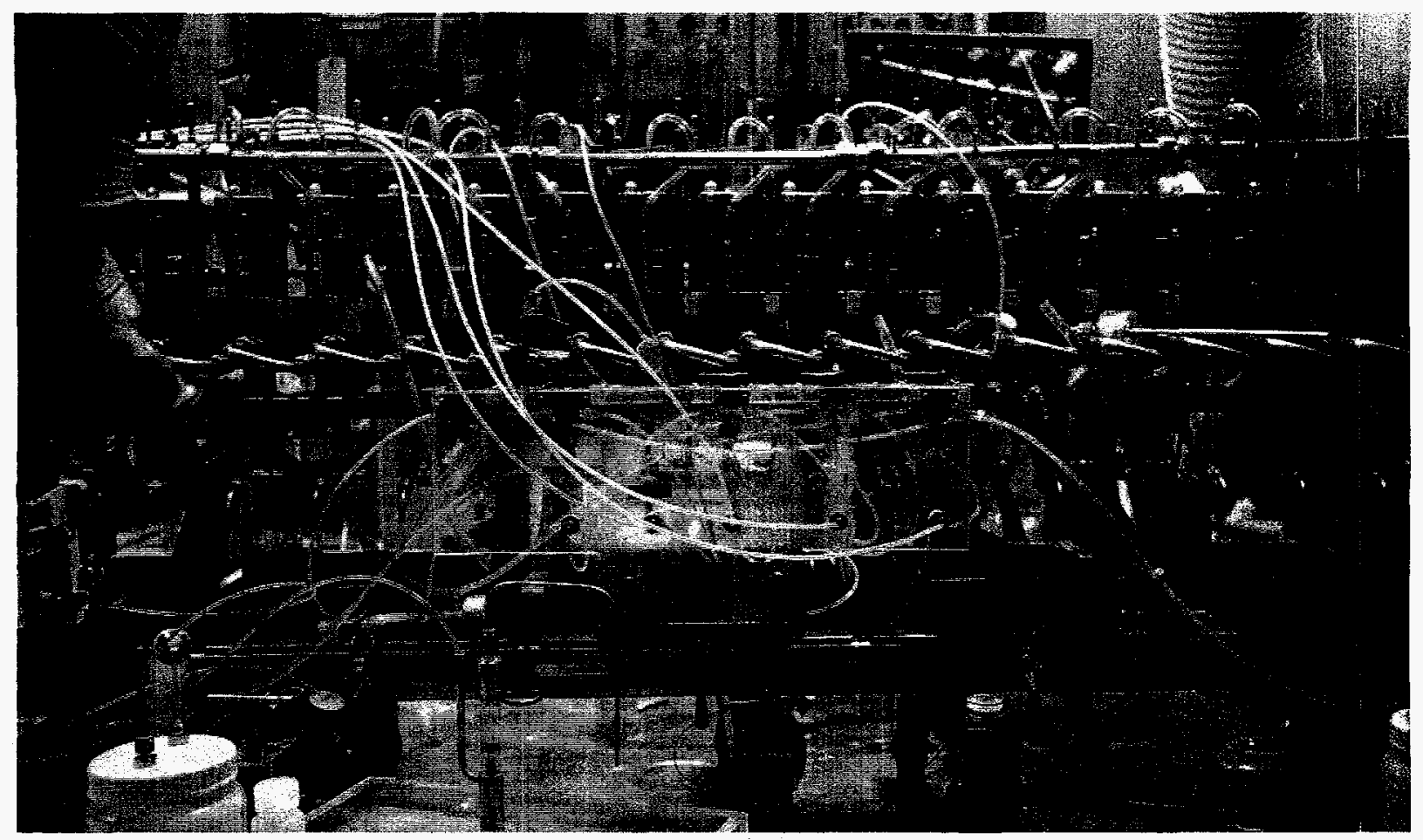

Figure 1. 2-cm diameter centrifugal contactors installed in the RAL shielded cell.

The 2-cm centrifugal contactors do not have provisions for sampling the aqueous and organic solutions exiting individual stages during operation. The aqueous raffinate, strip product, and solvent recycle streams were sampled by routing the solution draining to a receiving vessel into a sample bottle during the actual flowsheet test. Individual stage samples were taken by draining the contactor stages after shutdown.

An air purge system was connected to the contactor bearing housings. Purge air was required in order to protect the motor body, shaft, and bearings from corrosive process fumes. Air to the bearing housings passed through a rotameter. The air flowrate through the rotameter could be adjusted from zero to five scth. Air from the rotameter was split to feed each of the 24 contactors. The diameter of the air manifold was large ( $1 / 2$ in. o.d. tubing), while the diameter of the tubes leading from the manifold to the contactors was small (1/8 in. o.d. tubing), resulting in the air flow to each contactor being approximately equivalent. The offgas from the bearing purge system was vented to the cell. 


\title{
METHODOLOGYIEXPERIMENTAL PROCEDURE
}

\author{
WM-183 Waste
}

Sodium-bearing waste, obtained from tank WM-183 in June 1996, was used as feed solution for this testing. The WM-183 waste was passed through an AMP/PAN ion exchange column as part of Cs removal development studies. The waste was also filtered prior to testing using a 0.45 -micron filter. Currently, approximately 5.7 million liters of SBW are stored in six tanks. The composition in each tank varies; however, the composition of the solution in tank WM-183 is representative of the solution in all the tanks. The chemical composition of the WM- 183 waste, along with the average composition of the current SBW inventory, is shown in Table 2.

Table 2. WM-183 waste and average SBW tank compositions.

\begin{tabular}{cccccc}
\hline Component & WM-183 & $\begin{array}{c}\text { Average } \\
\text { SBW }\end{array}$ & Component & WM-183 & $\begin{array}{c}\text { Average } \\
\text { SBW }\end{array}$ \\
\hline Acid $(M)$ & 1.80 & 1.59 & $\mathrm{SO}_{4}(M)$ & $0.066^{\mathrm{a}}$ & 0.050 \\
$\mathrm{Al}(M)$ & 0.58 & 0.64 & $\mathrm{Zr}(M)$ & $4.2 \mathrm{E}-04^{\mathrm{a}}$ & 0.002 \\
$\mathrm{~B}(M)$ & $0.013^{\mathrm{a}}$ & 0.018 & $\mathrm{Alpha}(\mathrm{nCi} / \mathrm{g})$ & 540 & 369.4 \\
$\mathrm{Ca}(M)$ & 0.038 & 0.054 & ${ }^{241} \mathrm{Am}(\mathrm{nCi} / \mathrm{g})$ & 35 & 90.1 \\
$\mathrm{Cl}(M)$ & $0.011^{\mathrm{a}}$ & 0.028 & ${ }^{238} \mathrm{Pu}(\mathrm{nCi} / \mathrm{g})$ & 325 & 34.7 \\
$\mathrm{Cr}(M)$ & $0.016^{\mathrm{a}}$ & 0.003 & ${ }^{239} \mathrm{Pu}(\mathrm{nCi} / \mathrm{g})$ & 122 & 244.6 \\
$\mathrm{Fe}(M)$ & 0.054 & 0.022 & $\mathrm{U}(\mathrm{mg} / \mathrm{L})$ & 123 & 119.2 \\
$\mathrm{Hg}(M)$ & 0.0023 & 0.0011 & ${ }^{237} \mathrm{~Np}(\mathrm{nCi} / \mathrm{g})$ & $<6.5^{\mathrm{a}}$ & 0.36 \\
$\mathrm{~K}(M)$ & 0.11 & 0.206 & ${ }^{137} \mathrm{Cs}\left(\mathrm{Ci} / \mathrm{m}^{3}\right)$ & $218^{\mathrm{a}}$ & 41 \\
$\mathrm{Na}(M)$ & 0.81 & 1.9 & ${ }^{90} \mathrm{Sr}\left(\mathrm{Ci} / \mathrm{m}^{3}\right)$ & $240^{\mathrm{a}}$ & 38 \\
$\mathrm{NO}(M)$ & $5.24^{\mathrm{a}}$ & 5.07 & & & \\
$\mathrm{~Pb}(M)$ & 0.0011 & 0.0012 & & & \\
\hline a. Concentration in WM-183 prior to AMP/PAN ion exchange studies & & \\
\hline
\end{tabular}

\section{TRUEX Solvent}

The composition of the TRUEX solvent used in these tests was $0.2 M C M P O$ and $1.4 M$ TBP in Isopar $\mathrm{L}^{\circledR}$. The solvent was prepared by the ICPP Quality Control Laboratory and was used previously for flowsheet development studies in $2.0-\mathrm{cm}$ and $5.5-\mathrm{cm}$ centrifugal contactor flowsheet testing. The purity and composition of the TRUEX solvent were established prior to use in the centrifugal contactors. Impurities in the CMPO, resulting from acid hydrolysis, radiolytic degradation, or residual manufacturing impurities, may hinder the ability to strip the actinides from the TRUEX solvent. ${ }^{7}$ The 
distribution coefficient for ${ }^{241} \mathrm{Am}$ is particularly sensitive to CMPO impurities. Therefore, the distribution coefficient for ${ }^{241} \mathrm{Am}$ was evaluated as a function of nitric acid concentration from $\mathrm{HNO}_{3}$ solutions to evaluate CMPO purity and solvent composition. This method of determining ${ }^{241} \mathrm{Am}$ distributions as a function of nitric acid concentration was established as a quality control procedure and was used to test the initial TRUEX solvent and the TRUEX solvent from each flowsheet test. ${ }^{8}$ If the results were comparable to literature values, the solvent was suitable for extraction studies.

\section{Analytical}

The countercurrent extraction test which was performed resulted in a considerable number of samples requiring analysis. Analyses for this testing included total alpha, ${ }^{241} \mathrm{Am},{ }^{238} \mathrm{Pu},{ }^{239} \mathrm{Pu}, \mathrm{U}, \mathrm{Al}, \mathrm{Ca}$, $\mathrm{Fe}, \mathrm{Hg}, \mathrm{Na}, \mathrm{K}, \mathrm{Pb}$, and $\mathrm{H}^{+}$. Alpha spectroscopy was used for $\mathrm{Am}$ and $\mathrm{Pu}$ analyses, and mass spectroscopy was used for $U$ analyses. Inductively coupled plasma atomic emission spectroscopy (ICP$\mathrm{AES}$ ) was used for $\mathrm{Al}, \mathrm{Ca}, \mathrm{Fe}$, and $\mathrm{Pb}$ analyses, atomic fluorescence spectroscopy for $\mathrm{Hg}$ analyses, and atomic absorption spectrophotometry (AAS) for $\mathrm{Na}$ and $\mathrm{K}$ analyses.

Most organic and aqueous samples were diluted prior to removal from the RAL hot cell due to their intense radioactivity. Aqueous dilutions were made in 3 volume $\% \mathrm{HNO}_{3}$ and organic dilutions were made in unused solvent. Dilutions as great as $0.5 \mathrm{~mL}$ to $100.5 \mathrm{~mL}$ were needed to bring the samples out of the hot cell. Additional dilutions on some aqueous samples were required for analytical, as opposed to radiological, purposes.

Organic samples could not be analyzed directly; therefore, a $2 \mathrm{~mL}$ aliquot of each organic dilution was contacted with $10 \mathrm{~mL}$ of $0.25 \mathrm{M}$ 1-hydroxyethane 1,1-diphosphonic acid (HEDPA) made up in 0.04 $M \mathrm{HNO}_{3}(\mathrm{O} / \mathrm{A}=0.2)$ as part of the analytical preparation of the organic sample. HEDPA has been shown to quantitatively extract $\mathrm{Al}, \mathrm{Ca}, \mathrm{Fe}, \mathrm{Na}, \mathrm{K}, \mathrm{Pb}$, and the actinides from the TRUEX solvent. ${ }^{6,9,10}$ HEDPA will not strip $\mathrm{Hg}$ from the TRUEX solvent. Therefore, an additional $1 \mathrm{~mL}$ aliquot was taken from the TRUEX dilution and contacted with $5 \mathrm{~mL}$ of $0.25 M \mathrm{Na}_{2} \mathrm{CO}_{3}$. Sodium carbonate has been shown to quantitatively back extract $\mathrm{Hg}$ from the TRUEX solvent. ${ }^{6,9,10}$ Mercury analyses of the resulting aqueous solutions were conducted by atomic fluorescence spectroscopy.

\section{TRUEX Flowsheet Demonstration}

Based on the results of TRUEX flowsheet testing performed at the ICPP using actual SBW in 2.0$\mathrm{cm}$ diameter centrifugal contactors, an optimized TRUEX flowsheet was recommended for testing in the $2.0-\mathrm{cm}$ centrifugal contactors using actual ICPP SBW. ${ }^{6}$ This flowsheet consists of six stages of extraction at an $\mathrm{O} / \mathrm{A}$ of 0.33 , four stages of $0.1 \mathrm{MHNO}_{3}$ scrub at an $\mathrm{O} / \mathrm{A}$ of 1.5 , six stages of $0.01 \mathrm{M} !$ HEDPA in $0.01 \mathrm{MHNO}_{3}$ strip at an O/A of 1.0, two stages of $0.25 \mathrm{MNa}_{2} \mathrm{CO}_{3}$ wash at an O/A of 1.0 , and two stages of $0.1 \mathrm{MHNO}_{3}$ rinse at an O/A of 6.0. The resulting flowsheet used for the TRUEX flowsheet testing is shown in Figure 2. There is no benefit for the fractionation of individual actinicles (i.e., Am from Pu) since all the actinides will be disposed of in the high-activity waste glass. Therefore, a gross actinide stripping agent (HEDPA) was used. The concentration of HEDPA was reduced from $0.04 M$ to $0.01 M$ for this test in order to reduce the quantity of phosphorus in the HLW strip product. The presence of phosphorus in the $\mathrm{HLW}$ fraction will increase the quantity of $\mathrm{HLW}$ glass product. Another change made to the flowsheet for this testing was reducing the number of extraction stages from eight to six, the number of scrub stages from five to four, and the number of carbonate wash stages from three to two. It should be noted that one contactor stage was not operational in the initial flowsheet test, essentially eliminating the scrub section. ${ }^{6}$ 


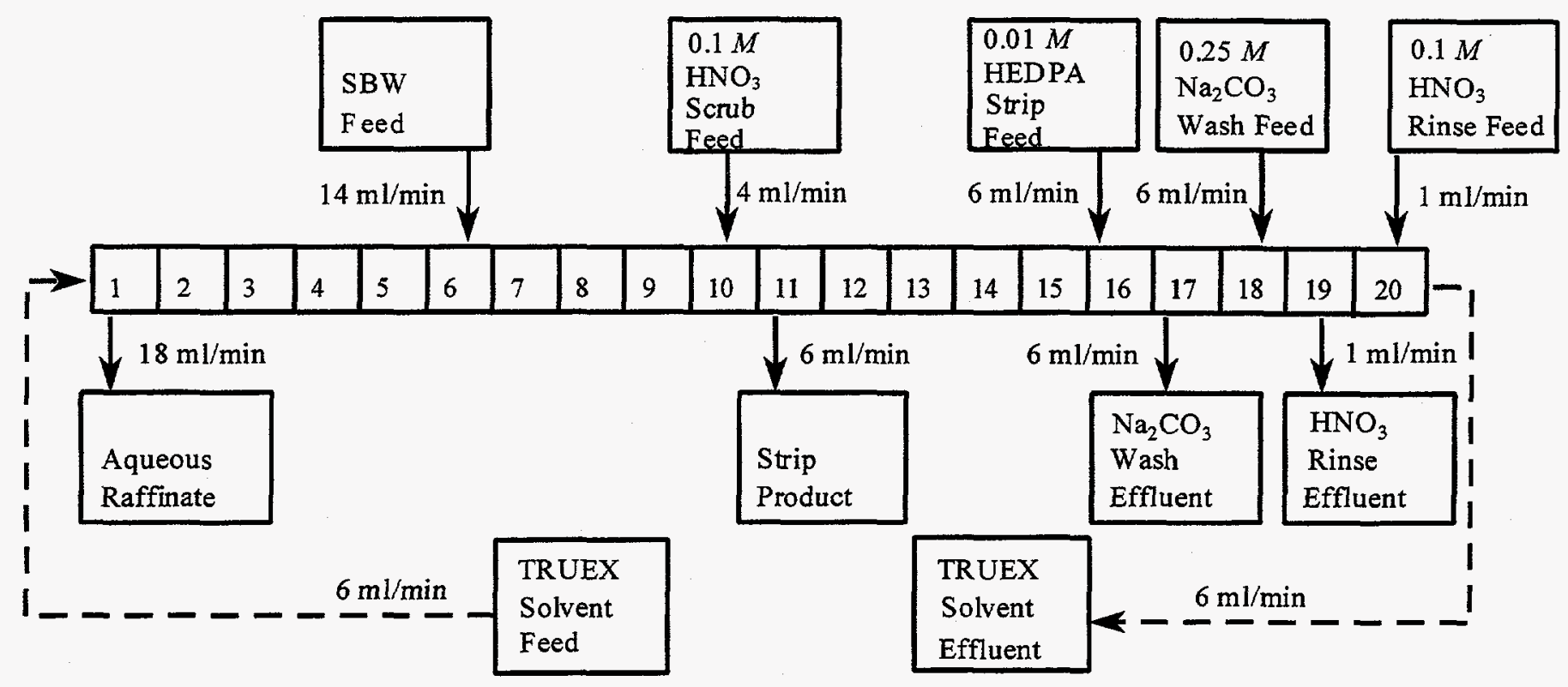

Figure 2. Flowsheet for TRUEX demonstration.

The goals of the TRUEX flowsheet testing were to:

(1) Evaluate the effectiveness of the TRUEX flowsheet in separating the actinides from actual SBW.

(2) Determine the concentrations and distribution coefficients of total alpha, ${ }^{241} \mathrm{Am}, \mathrm{Pu}, \mathrm{U}^{+} \mathrm{H}^{+}, \mathrm{Fe}$, and $\mathrm{Hg}$ for each stage at steady-state conditions.

(3) Determine if any precipitate or third phase formation problems exist with this flowsheet.

(4) Evaluate the effectiveness of reducing the concentration of HEDPA to $0.01 M$ in the strip feed.

(5) Determine the operational time required for the mass transfer in the contactors to reach steady state.

The time required to reach steady state was evaluated by sampling the aqueous raffinate and strip product streams at 15 to 30 minute intervals and determining when component concentrations were no longer changing with time. These data are required in order to verify steady state was achieved prior to shutdown and sampling of each stage.

TRUEX flowsheet testing was performed as follows. The centrifugal contactor motors were started at 3,600 rpm. All aqueous solution flows, except for the actual SBW, were established. Simulant flow, consisting of $1.9 \mathrm{MHNO}_{3}, 0.6 \mathrm{MAl}_{2} \mathrm{NO}_{3}$, and $0.6 \mathrm{MNaNO}$ was established for the SBW feed. Thirty minutes after the start of the aqueous feeds, solvent feed flow was established. Once solvent flow was seen exiting stage 20, actual SBW feed (WM-183) was started. Samples were taken from the aqueous raffinate and strip product streams at intervals of 30,60,75, and 90 minutes after the start of WM-183 feed. Level readings on each of the feed tanks were also noted in order to determine actual solution flowrates based on tank depletion rates. Approximately 100 minutes after the start of WM-183 feed, samples were taken of the aqueous raffinate, strip product, $\mathrm{Na}_{2} \mathrm{CO}_{3}$ wash, $\mathrm{HNO}_{3}$ rinse, and solvent 
effluent streams. The centrifugal contactors were then shutdown by simultaneously stopping the feed pumps and contactor motors. Each stage remains approximately at steady-state operating conditions with this type of shutdown. This allowed aqueous and organic samples to be taken from each stage and, therefore, distribution coefficients to be determined for each of the 20 stages.

After shutdown, individual stage samples were taken as follows. The solution from each stage was drained into individual $60 \mathrm{~mL}$ sample bottles. The phases were re-equilibrated by shaking the bottles with a manipulator for several minutes each. Re-equilibration of the phases serves to evaluate distribution coefficients of the individual species under hypothetical conditions of $100 \%$ stage efficiency. The re-equilibrated solution from each stage was then poured into a clean separatory funnel, allowed to stand for five to ten minutes, and the aqueous and organic phases were separated. 


\section{RESULTS AND DISCUSSION}

\section{TRUEX Flowsheet Demonstration}

\section{Contactor Operation}

Actual solution flowrates were calculated from feed tank depletion rates and are compared to the desired flowrates in Table 3. Flooding or third phase formation was not observed during testing. Reequilibration of the solution drained from stage 11 (strip product stage) resulted in the formation of a white precipitate. This precipitate was not observed on any other stage or in the samples taken during operation.

Table 3. Flowrates and O/A ratios for TRUEX flowsheet testing.

\begin{tabular}{lcccccc}
\hline & & \multicolumn{2}{c}{ Flowrate $(\mathrm{mL} / \mathrm{min})$} & \multicolumn{2}{c}{ O/A Ratio } & $\begin{array}{l}\text { Total Flow } \\
\text { (mL/min) }\end{array}$ \\
Section & Phase & Desired & Actual & Desired & Actual & $\ldots .-$ \\
\hline All & Org. & 6.0 & 5.7 & -- & -- \\
Extraction & Aq. & 14.0 & 13.7 & 0.33 & 0.32 & 23.4 \\
Scrub & Aq. & 4.0 & 4.0 & 1.5 & 1.5 & 9.7 \\
Strip & Aq. & 6.0 & 5.7 & 1.0 & 1.0 & 11.4 \\
$\mathrm{Na}_{2} \mathrm{CO}_{3}$ Wash & Aq. & 6.0 & 6.1 & 1.0 & 0.93 & 11.8 \\
Acid Rinse & Aq. & 1.0 & 1.1 & 6.0 & 5.2 & 6.8 \\
\hline
\end{tabular}

\section{Time to Reach Steady State}

The concentrations of gross alpha, $\mathrm{H}^{+}$, and $\mathrm{Hg}$ as a function of time $\left(\mathrm{T}_{0}=\right.$ start of WM-183 feed) are given in Figures 3 through 5 for the aqueous raffinate and strip product. It was assumed that steady state was reached when the concentration of the components varied by less than the analytical error associated with the sample analyses.

In the strip product, $\mathrm{H}^{+}$reached steady state within 30 minutes, total alpha within 60 minutes, and $\mathrm{Hg}$ within 75 minutes. In the aqueous raffinate, acid reached steady state within 30 minutes and $\mathrm{Hg}$ within 75 minutes. Total alpha activity in the raffinate did not reach steady state, decreasing throughout the run. Residual activity is present in the centrifugal contactors from previous testing. Although considerable flushing of the contactors is performed after each test, contamination remains in the contactors and process lines. It is expected that this residual contamination was slowly being flushed out of the contactors during testing, resulting in a steady drop of the activity in the raffinate. 


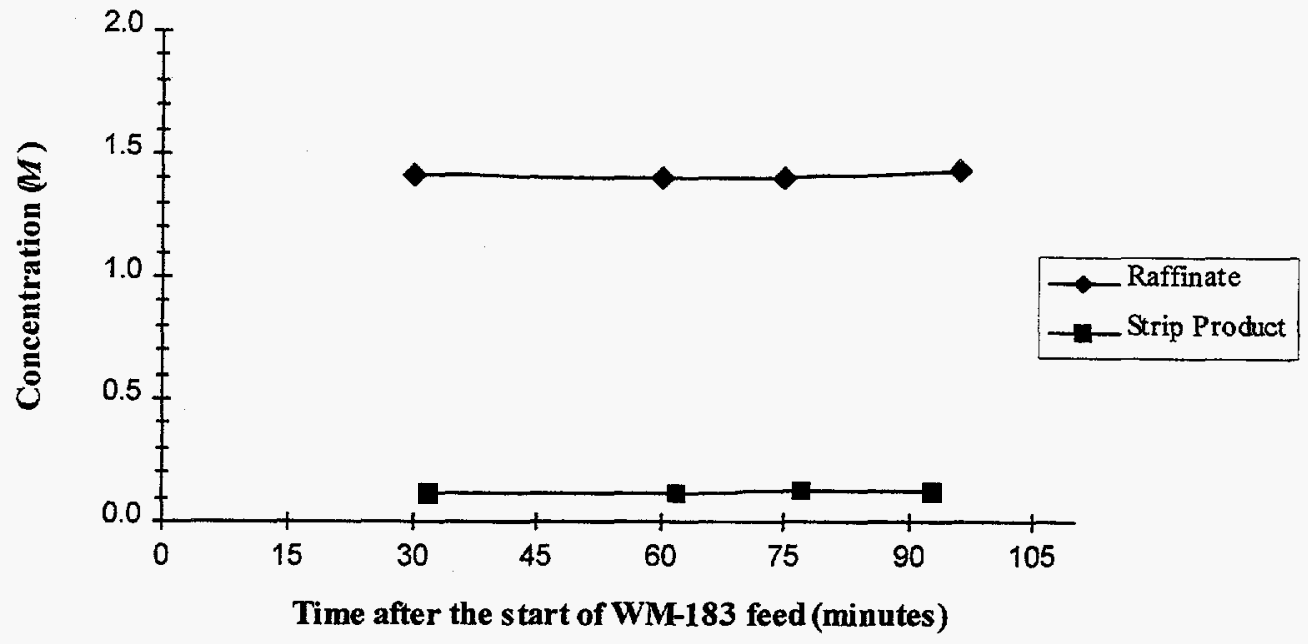

Figure 3. Acid approach to steady state.

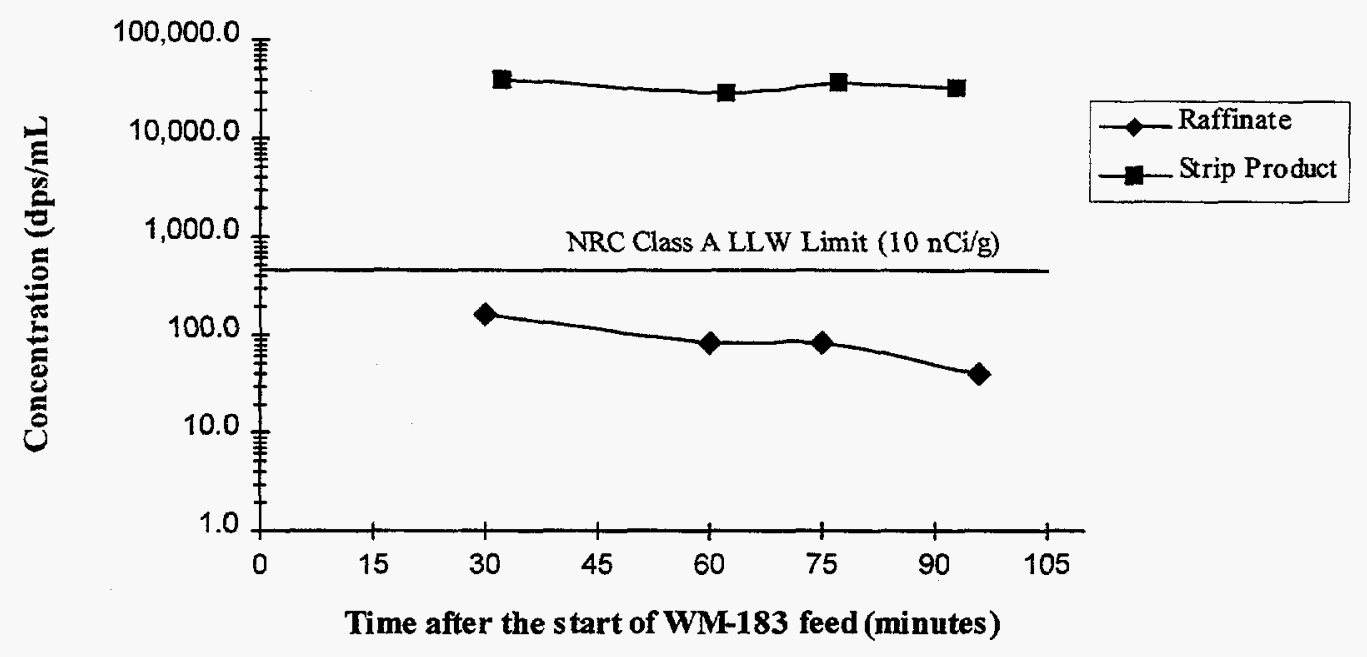

Figure 4. Total alpha approach to steady state. 


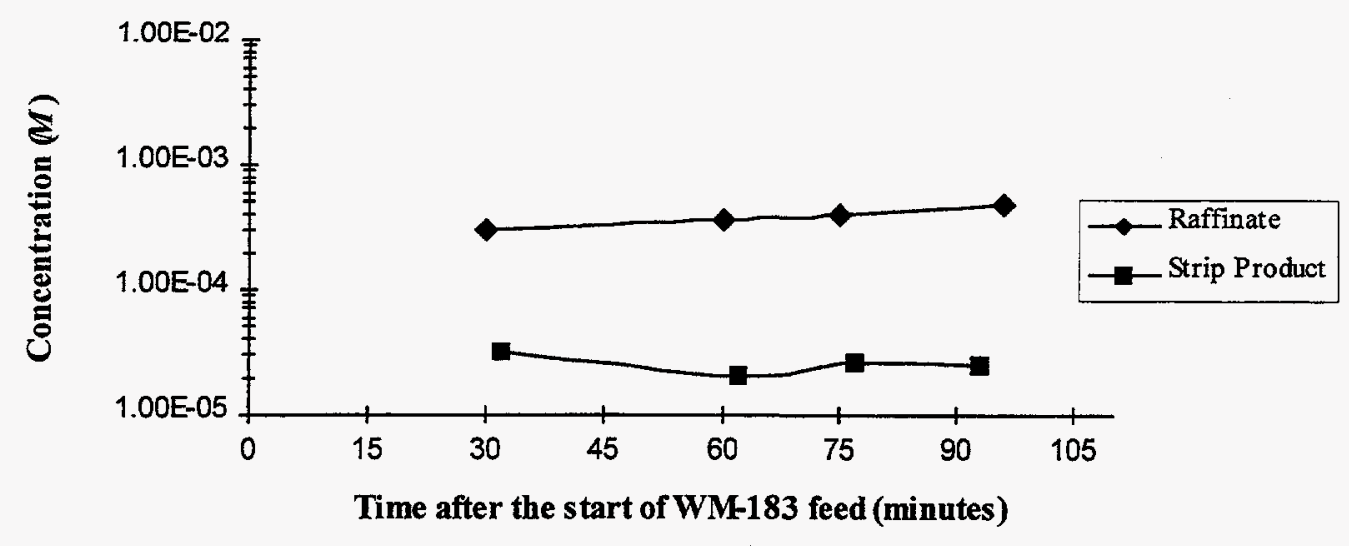

Figure 5. Mercury approach to steady state.

\section{Concentrations at Shutdown}

The concentrations of total alpha, ${ }^{241} \mathrm{Am},{ }^{238} \mathrm{Pu},{ }^{239} \mathrm{Pu},{ }^{235} \mathrm{U},{ }^{238} \mathrm{U}_{,} \mathrm{H}^{+}, \mathrm{Al}, \mathrm{Ca}, \mathrm{Fe}, \mathrm{Hg}, \mathrm{Na}, \mathrm{K}$, and $\mathrm{Pb}$ in each stream immediately prior to shutdown are given in Figure 6. Material balances for gross alpha, ${ }^{241} \mathrm{Am},{ }^{238} \mathrm{Pu},{ }^{239} \mathrm{Pu},{ }^{238} \mathrm{U}, \mathrm{Fe}, \mathrm{Hg}, \mathrm{Na}$, and $\mathrm{K}$ are given in Table 4. Distribution coefficients were calculated for gross alpha, ${ }^{241} \mathrm{Am},{ }^{238} \mathrm{Pu},{ }^{239} \mathrm{Pu},{ }^{235} \mathrm{U},{ }^{238} \mathrm{U}, \mathrm{Fe}, \mathrm{H}^{+}$, and $\mathrm{Hg}$ for many of the 20 stages. The resulting distribution coefficients are given in Tables 5 and 6 . A discussion of the behavior of each component follows.

Total Alpha. The gross alpha activity was reduced from $2.5 \mathrm{E}+04 \mathrm{dps} / \mathrm{mL}$ in the feed to $41 \mathrm{dps} / \mathrm{mL}$ in the aqueous raffinate immediately prior to shutdown. This corresponds to a removal efficiency of $99.79 \%$. A gross alpha activity of $41 \mathrm{dps} / \mathrm{mL}$ corresponds to $0.9 \mathrm{nCi} / \mathrm{g}$ which is well below the NRC Class A LLW requirement of $10 \mathrm{nCi} / \mathrm{g}$ for non-TRU waste. Total alpha analyses of the aqueous solution in each of the extraction stages indicates that most of the separation of the alpha activity occurred on the first three stages of extraction (stages 4 through 6). On stages 1 through 3, little additional separation occurred. Residual contamination of the centrifugal contactors from previous testing with actual waste solutions is believed to have prevented the total alpha activity from being reduced further. The strip section was effective in back-extracting the actinides from the TRUEX solvent, removing $99.4 \%$ of the gross alpha activity from the solvent with six strip stages.

A poor overall material balance was obtained for the total alpha activity $(58 \%)$, indicating that a precipitate may have formed in the strip section. A precipitate was not visually apparent in the strip product sample or in the stage 11 centrifugal contactor; however, a precipitate formed in the solution after it was drained from stage 11 after shutdown and re-equilibrated. It should be noted that precipitates were not observed and good material balances were obtained for the actinides with previous flowsheet testing using WM-183 waste. ${ }^{6}$ One difference between this test and the previous flowsheet test is that the HEDPA concentration was reduced from $0.04 M$ to $0.01 M$. Also, the scrub section was operational in this test but was not in the previous flowsheet test. 


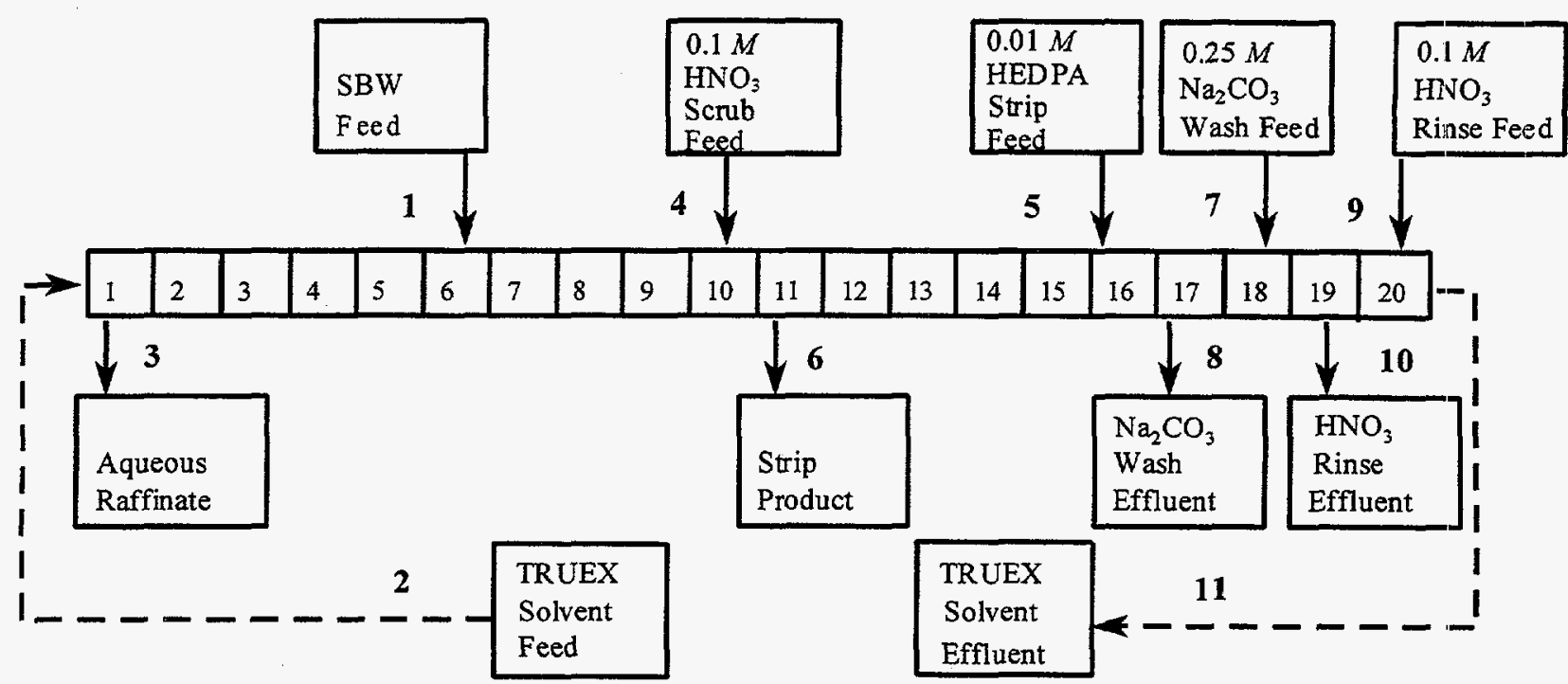

\begin{tabular}{|c|c|c|c|c|c|c|c|c|c|c|c|}
\hline Component & $\begin{array}{c}\text { SBW } \\
\text { Feed } \\
1 \\
\end{array}$ & $\begin{array}{l}\text { TRUEX } \\
\text { Solvent } \\
\text { Feed } \\
2 \\
\end{array}$ & $\begin{array}{c}\text { LAW } \\
\text { Raff. } \\
3 \\
\end{array}$ & $\begin{array}{c}\text { Scrub } \\
\text { Feed } \\
4 \\
\end{array}$ & $\begin{array}{c}\text { Strip } \\
\text { Feed } \\
5 \\
\end{array}$ & $\begin{array}{c}\text { Strip } \\
\text { Product } \\
6 \\
\end{array}$ & $\begin{array}{c}\mathrm{Na}_{2} \mathrm{CO}_{3} \\
\text { Feed } \\
7 \\
\end{array}$ & $\begin{array}{c}\mathrm{Na}_{2} \mathrm{CO}_{3} \\
\text { Effluent } \\
8\end{array}$ & $\begin{array}{c}\text { Acid } \\
\text { Rinse } \\
\text { Feed } \\
9 \\
\end{array}$ & $\begin{array}{c}\text { Acid } \\
\text { Rinse } \\
\text { Effluent } \\
10 \\
\end{array}$ & $\begin{array}{c}\text { TRUEX } \\
\text { Solvent } \\
\text { Effluent } \\
11 \\
\end{array}$ \\
\hline $\mathrm{H}^{+}(M)$ & 1.8 & $\cdots$ & 1.4 & 0.1 & 0.01 & 0.12 & --- & - & 0.1 & $\mathrm{nd}^{\mathrm{a}}$ & nd \\
\hline HEDPA $(M)$ & $\cdots$ & --- & --- & $\cdots$ & 0.01 & 0.01 & -- & --- & -- & -- & -- \\
\hline $\mathrm{Na}_{2} \mathrm{CO}_{3}(M)$ & -- & -- & -- & -- & -- & --- & 0.25 & 0.25 & - & --- & -- \\
\hline Al $(M)$ & 0.58 & -- & 0.45 & -- & --- & $<0.16$ & $\cdots$ & $<8.5 \mathrm{E}-04$ & -- & $<8.5 \mathrm{E}-104$ & nd \\
\hline $\mathrm{Ca}(M)$ & 0.038 & --- & 0.027 & -- & -- & $<0.022$ & $\cdots$ & $<1.2 \mathrm{E}-04$ & $\cdots$ & $<1.2 \mathrm{E}-04$ & nd \\
\hline $\mathrm{Fe}(M)$ & 0.054 & --- & 0.039 & -- & -- & $9.2 \mathrm{E}-04$ & -- & $6.5 \mathrm{E}-06$ & $\cdots$ & $9.7 \mathrm{E}-06$ & $4.8 \mathrm{E}-05$ \\
\hline $\mathrm{Hg}(M)$ & $2.3 \mathrm{E}-03$ & $\cdots$ & $4.8 \mathrm{E}-04$ & -- & --- & $2.5 \mathrm{E}-05$ & -- & $4.2 \mathrm{E}-03$ & -- & $3.7 \mathrm{E}-06$ & $2.1 \mathrm{E}-06$ \\
\hline $\mathrm{K}(M)$ & 0.11 & -- & 0.11 & --- & --- & $1.5 \mathrm{E}-04$ & -- & $7.3 \mathrm{E}-06$ & - & $1.3 \mathrm{E}-05$ & nd \\
\hline $\mathrm{Na}(M)$ & 0.81 & -- & 0.61 & -- & --- & $1.2 \mathrm{E}-03$ & -- & nd & - & $1.5 \mathrm{E}-03$ & nd \\
\hline $\mathrm{Pb}(M)$ & $1.1 \mathrm{E}-03$ & -- & $1.3 \mathrm{E}-03$ & - & --- & $<2.9 \mathrm{E}-04$ & $\cdots$ & nd & $\cdots$ & nd & $<2.9 \mathrm{E}-04$ \\
\hline Alpha (dps/mL) & $2.5 \mathrm{E}+04$ & $\cdots$ & 41 & - & -- & $3.4 E+04$ & $\cdots$ & 549 & -- & 36 & 3.5 \\
\hline 238Pu (dps/mL) & $1.5 \mathrm{E}+04$ & --- & 3.7 & - & -- & $1.9 E+04$ & $\cdots$ & 392 & -- & 21 & nd \\
\hline${ }^{239} \mathrm{Pu}(\mathrm{dps} / \mathrm{mL})$ & $5.6 \mathrm{E}+03$ & -- & 1.5 & -- & -- & $7.0 \mathrm{E}+03$ & -- & 147 & -- & 8.0 & nd \\
\hline $235 \mathrm{U}(\mathrm{ppm})$ & 13 & --- & 0.015 & --- & -- & 28 & -- & 0.53 & --- & 1.4 & 0.017 \\
\hline 238U (ppm) & 110 & - & 0.21 & -- & --- & 242 & -- & 4.6 & -- & 11 & 0.17 \\
\hline $\begin{array}{l}241_{\text {Am }}(\mathrm{dps} / \mathrm{mL}) \\
\text { Flowrate }\end{array}$ & $1.6 \mathrm{E}+03$ & - & 2.0 & -- & -- & $3.0 \mathrm{E}+03$ & -- & 5.6 & -- & 0.91 & 0.45 \\
\hline$(\mathrm{mL} / \mathrm{min})$ & 13.7 & 5.7 & 17.7 & 4.0 & 5.7 & 5.7 & 6.1 & 6.1 & 1.1 & 1.1 & 5.7 \\
\hline
\end{tabular}

Figure 6. TRUEX flowsheet test concentrations at shutdown. 
Table 4. Percentage of component in each of the effluent streams for TRUEX flowsheet testing.

\begin{tabular}{|c|c|c|c|c|c|c|c|c|c|}
\hline Stream & Gross Alpha & ${ }^{24 !} \mathrm{Am}$ & ${ }^{238} \mathrm{Pu}$ & ${ }^{239} \mathrm{Pu}$ & ${ }^{238} \mathrm{U}$ & $\mathrm{K}$ & $\mathrm{Na}$ & $\mathrm{Hg}$ & $\mathrm{Fe}$ \\
\hline $\begin{array}{l}\text { Aqueous } \\
\text { Raffinate }\end{array}$ & $0.21 \%$ & $0.16 \%$ & $0.03 \%$ & $0.03 \%$ & $0.24 \%$ & $131.1 \%$ & $98.5 \%$ & $26.3 \%$ & $92.9 \%$ \\
\hline $\begin{array}{l}\text { Strip } \\
\text { Product }\end{array}$ & $56.8 \%$ & $77.0 \%$ & $51.7 \%$ & $51.9 \%$ & $91.5 \%$ & $0.06 \%$ & $0.06 \%$ & $0.45 \%$ & $0.71 \%$ \\
\hline $\begin{array}{l}\mathrm{Na}_{2} \mathrm{CO}_{3} \\
\text { Effluent }\end{array}$ & $0.98 \%$ & $0.15 \%$ & $1.2 \%$ & $1.2 \%$ & $1.8 \%$ & $0.003 \%$ & nd & $79.1 \%$ & $0.005 \%$ \\
\hline $\begin{array}{l}\text { Rinse } \\
\text { Effluent }\end{array}$ & $0.01 \%$ & $0.004 \%$ & $0.01 \%$ & $0.01 \%$ & $0.8 \%$ & $0.0009 \%$ & $0.014 \%$ & $0.01 \%$ & $0.001 \%$ \\
\hline $\begin{array}{l}\text { Solvent } \\
\text { Effluent }\end{array}$ & $0.01 \%$ & 0.01 & $\mathrm{nd}^{\mathrm{a}}$ & nd & $0.07 \%$ & nd & nd & $0.04 \%$ & $0.04 \%$ \\
\hline $\begin{array}{l}\text { Mass } \\
\text { Balance }^{b}\end{array}$ & $58.0 \%$ & $77.3 \%$ & $52.9 \%$ & $53.1 \%$ & $94.5 \%$ & $131.1 \%$ & $98.6 \%$ & $105.9 \%$ & $93.6 \%$ \\
\hline
\end{tabular}

Table 5. Gross alpha, ${ }^{241} \mathrm{Am},{ }^{238} \mathrm{Pu},{ }^{239} \mathrm{Pu},{ }^{235} \mathrm{U}$ and ${ }^{238} \mathrm{U}$ distribution coefficients for TRUEX flowsheet testing.

\begin{tabular}{|c|c|c|c|c|c|c|c|}
\hline Stage & & $\mathrm{D}_{\text {gross alpha }}$ & $D_{\text {Am-241 }}$ & $\mathrm{D}_{\mathrm{Pu}-238}$ & $\mathrm{D}_{\mathrm{Pu}-239}$ & $\mathrm{D}_{\mathrm{U}-235}$ & $D_{U-238}$ \\
\hline \multirow{6}{*}{ Extraction } & 1 & nda & nd & nd & nd & $>1.3$ & 14.9 \\
\hline & 2 & nd & nd & nd & nd & 2.6 & 13.6 \\
\hline & 3 & nd & nd & nd & nd & $>3.2$ & 14.1 \\
\hline & 4 & nd & 19.1 & nd & nd & $>2.0$ & 13.3 \\
\hline & 5 & 8.9 & 31.2 & nd & nd & $>70$ & 46.8 \\
\hline & 6 & 607 & 53.6 & 12478 & nd & $>1292$ & 176.3 \\
\hline \multirow[t]{4}{*}{ Scrub } & 7 & 260 & 1070 & 9934 & nd & 4726 & 1047 \\
\hline & 8 & nd & nd & nd & nd & $>210$ & 108 \\
\hline & 9 & 33 & 2.6 & 1180 & 996 & 49.6 & 215 \\
\hline & 10 & 100 & 7.0 & 3014 & 4479 & 277 & 232 \\
\hline \multirow[t]{6}{*}{ Strip } & 11 & 0.57 & 0.56 & 0.48 & 0.65 & 0.91 & 1.6 \\
\hline & 12 & 0.23 & 0.33 & 0.35 & 3.8 & 0.03 & 0.18 \\
\hline & 13 & 0.54 & 1.3 & 0.55 & 0.63 & 0.16 & 0.79 \\
\hline & 14 & 0.80 & 0.5 & 0.90 & 1.0 & 0.07 & 0.26 \\
\hline & 15 & nd & nd & nd & nd & nd & nd \\
\hline & 16 & 1.6 & 0.42 & 0.34 & 1.1 & 0.14 & 0.78 \\
\hline \multirow[t]{2}{*}{ Wash } & 17 & 0.078 & 0.80 & 0.14 & 0.20 & 0.08 & 0.13 \\
\hline & 18 & 0.34 & 0.63 & 0.20 & 0.26 & 3.0 & 2.3 \\
\hline \multirow[t]{2}{*}{ Rinse } & 19 & 3.8 & 0.49 & 9.4 & 12.2 & 27.7 & 71.8 \\
\hline & 20 & 6.5 & 1.3 & 8.0 & 7.0 & $>25$ & $>892$ \\
\hline
\end{tabular}


Table 6. $\mathrm{H}^{+}, \mathrm{Fe}$, and $\mathrm{Hg}$ distribution coefficients for TRUEX flowsheet testing.

\begin{tabular}{|c|c|c|c|c|}
\hline Stage & & $\mathrm{D}_{\mathrm{H}^{+}}{ }^{\mathrm{a}}$ & $\mathrm{D}_{\mathrm{Fe}}$ & $\mathrm{D}_{\mathrm{Hg}}{ }^{\mathrm{a}}$ \\
\hline \multirow[t]{6}{*}{ Extraction } & 1 & 0.74 & nd & 2.6 \\
\hline & 2 & 0.67 & nd & 4.6 \\
\hline & 3 & 0.65 & 0.78 & 2.6 \\
\hline & 4 & 0.66 & 0.74 & 3.2 \\
\hline & 5 & 0.66 & 0.19 & 2.8 \\
\hline & 6 & 0.58 & nd & 2.7 \\
\hline \multirow[t]{4}{*}{ Scrub } & 7 & $n d^{b}$ & nd & 4.2 \\
\hline & 8 & nd & nd & 208 \\
\hline & 9 & nd & nd & 46 \\
\hline & 10 & nd & 1.7 & 46 \\
\hline \multirow[t]{6}{*}{ Strip } & 11 & nd & 3.6 & 43 \\
\hline & 12 & nd & nd & 368 \\
\hline & 13 & nd & 83 & 184 \\
\hline & 14 & nd & 2.1 & 992 \\
\hline & 15 & nd & nd & 1172 \\
\hline & 16 & nd & 7.7 & 1187 \\
\hline \multirow[t]{2}{*}{ Wash } & 17 & nd & 6.8 & 0.0055 \\
\hline & 18 & nd & 0.32 & 21.9 \\
\hline \multirow[t]{2}{*}{ Rinse } & 19 & nd & 4.4 & 6.0 \\
\hline & 20 & nd & nd & 4.4 \\
\hline $\begin{array}{l}\text { a. Organic concentr } \\
\text { b. Not determined. }\end{array}$ & & & & \\
\hline
\end{tabular}

Americium. The activity of ${ }^{241} \mathrm{Am}$ was reduced from $1.61 \mathrm{E}+03 \mathrm{dps} / \mathrm{mL}$ in the feed to $2.0 \mathrm{dps} / \mathrm{mL}$ in the aqueous raffinate immediately prior to shutdown. This corresponds to a removal efficiency of $99.84 \%$. The strip section was effective in back-extracting the Am from the TRUEX solvent, removing $99.96 \%$ of the Am from the solvent with the six strip stages. As with the total alpha analyses, a poor overall material balance was obtained for Am (77.3\%) indicating the formation of a precipitate in the strip section.

Plutonium. The activity of ${ }^{238} \mathrm{Pu}$ was reduced from $1.49 \mathrm{E}+04 \mathrm{dps} / \mathrm{mL}$ in the feed to $3.7 \mathrm{dps} / \mathrm{mL}$ in the aqueous raffinate immediately prior to shutdown. This corresponds to a removal efficiency of $99.97 \%$. The activity of ${ }^{239} \mathrm{Pu}$ was reduced from $5.58 \mathrm{E}+03 \mathrm{dps} / \mathrm{mL}$ in the feed to $1.5 \mathrm{dps} / \mathrm{mL}$ in the aqueous raffinate immediately prior to shutdown. This corresponds to a removal efficiency of $99.97 \%$. The strip section was effective in back-extracting the Pu from the TRUEX solvent, removing $99.8 \%$ of the $\mathrm{Pu}$ from the solvent with six strip stages. A poor overall material balance was obtained for ${ }^{238} \mathrm{Pu}$ and ${ }^{239} \mathrm{Pu}$ $(53 \%)$, also indicating that a precipitate may have formed in the strip section.

Uranium. The activity of ${ }^{235} \mathrm{U}$ was reduced from $12.9 \mathrm{ppm}$ in the feed to $0.015 \mathrm{ppm}$ in the aqueous raffinate immediately prior to shutdown. This corresponds to a removal efficiency of $99.85 \%$. The activity of ${ }^{238} \mathrm{U}$ was reduced from $110 \mathrm{ppm}$ in the feed to $0.21 \mathrm{ppm}$ in the aqueous raffinate immediately prior to shutdown. This corresponds to a removal efficiency of $99.76 \%$. The strip section was effective 
in back-extracting the $U$ from the TRUEX solvent, removing $99.2 \%$ of the $U$ from the solvent with the six strip stages. The remaining $U$ was washed from the solvent in the carbonate wash and acid rinse sections. The overall material balances for $U$ were good (93\%-94\%) indicating that little, if any, of the $U$ precipitated in the strip section.

Iron. Iron was partially extracted by the TRUEX process $\left(\mathrm{D}_{\mathrm{Fe}}=0.2\right.$ to 0.8$)$. Previous flowsheet testing with actual SBW from tank WM-183, in which the scrub section was not operating, resulted in $23 \%$ of the Fe extracting and exiting in the HLW strip product. With this test, however, the four scrub stages effectively removed the extracted iron from the solvent, resulting in only $0.7 \%$ of the Fe exiting with the $\mathrm{HLW}$ strip product. It is desirable to minimize the amount of $\mathrm{Fe}$ in the $\mathrm{HLW}$ strip product in order to reduce the volume of HLW glass generated.

Mercury. The TRUEX solvent extracted $74 \%$ of the $\mathrm{Hg}$ from the WM-183 waste. The $\mathrm{Hg}$ was not back-extracted in the strip section $\left(\mathrm{D}_{\mathrm{Hg}}=43\right.$ to 1187$)$; however, the $\mathrm{Na}_{2} \mathrm{CO}_{3}$ wash section effectively stripped the $\mathrm{Hg}$ from the solvent $\left(\mathrm{D}_{\mathrm{Hg}}=0.0055\right)$. As a result, $99.5 \%$ of the $\mathrm{Hg}$ was dispositioned between the $L L W$ raffinate and the $L L W ~ \mathrm{Na}_{2} \mathrm{CO}_{3}$ wash effluent.

$\mathrm{Hg}$ is extracted by the TRUEX solvent as $\mathrm{HgCl}_{2 .}{ }^{11}$ The extraction of $\mathrm{Hg}$ from SBW is dependent upon the $\mathrm{Cl} / \mathrm{Hg}$ ratio in the waste solution. The lower the $\mathrm{Cl} / \mathrm{Hg}$ ratio, the less $\mathrm{Hg}$ will be extracted. The $\mathrm{Cl} / \mathrm{Hg}$ ratio in the WM-183 feed is 4.8 . The average SBW composition has a $\mathrm{Cl} / \mathrm{Hg}$ ratio of 25.5 , indicating that more $\mathrm{Hg}$ will be extracted from waste in the other SBW tanks. Previous testing with a SBW simulant of similar composition to the average SBW resulted in $97 \%$ of the $\mathrm{Hg}$ extracted from the waste. $^{10}$

Nitric Acid. Distribution coefficients of $\mathrm{H}^{+}$in the extraction section ranged from 0.58 to 0.74 , resulting in an $\mathrm{H}^{+}$concentration of $1.1 \mathrm{M}$ in the TRUEX solvent exiting the extraction section. The 0.1 $M \mathrm{HNO}_{3}$ scrub effectively back-extracted the $\mathrm{HNO}_{3}$ from the TRUEX solvent. Reducing the concentration of acid in the TRUEX solvent increases the effectiveness of the strip section in backextracting the actinides.

Sodium and Potassium. Very little sodium or potassium was extracted by the TRUEX solvent. Only $0.07 \%$ of the sodium and $0.06 \%$ of the potassium were separated from the WM- 183 waste.

\section{Comparison With Results Obtained From Previous Flowsheet Testing}

Testing has been performed previously using 24 stages of 2-cm centrifugal contactors with actual SBW (WM-183) and with simulated SBW (WM-183 simulant) spiked with ${ }^{241} \mathrm{Am},{ }^{95} \mathrm{Zr}$, and ${ }^{203} \mathrm{Hg}$ tracers. ${ }^{6,10}$ Differences between the previous testing and this flowsheet test are (1) the number of extraction stages was reduced from eight to six, (2) the number of scrub stages was reduced from five to four, (3) the number of $\mathrm{Na}_{2} \mathrm{CO}_{3}$ wash stages was reduced from three to two, and (4) the concentration of HEDPA in the strip feed was reduced from $0.04 M$ to $0.01 M$. Also, the previous flowsheet testing with WM-183 waste was performed without a scrub section due to an inoperable contactor motor on the scrub feed stage. ${ }^{6}$ The composition of the simulated SBW is given in Table 7. Results obtained from the three flowsheet tests are compared in Table 8.

Results from each of the tests compare very well. Removal efficiencies for the actinides are very similar for each of the flowsheet tests. One difference between the results from the two tests with WM- 
183 is the amount of $\mathrm{Fe}$ in the strip product. In the first flowsheet test the scrub section was not operational, resulting in $23 \%$ of the Fe exiting in the strip product. With the optimized flowsheet the scrub section was operational and only $0.7 \%$ of the Fe exited with the strip product. Another difference with the optimized flowsheet is the larger activity of actinides in the wash effluent streams. With a lower concentration of HEDPA in the strip feed, it is possible that less of the actinides were back-extracted from the TRUEX solvent, allowing for subsequent stripping in the wash sections. However, it is not know if the increased activity in the wash effluents is due to a less efficient strip section or residual contamination in the centrifugal contactors.

Table 7. Composition of Simulated SBW.

\begin{tabular}{cccc}
\hline Component & $M$ & Component & $M$ \\
\hline Acid $\left(\mathrm{H}^{+}\right)$ & 1.26 & $\mathrm{~K}$ & $1.38 \mathrm{E}-01$ \\
$\mathrm{Al}$ & $5.63 \mathrm{E}-01$ & $\mathrm{Mn}$ & $1.42 \mathrm{E}-02$ \\
$\mathrm{~B}$ & $1.40 \mathrm{E}-02$ & $\mathrm{Mo}$ & $1.49 \mathrm{E}-03$ \\
$\mathrm{Cd}$ & $2.05 \mathrm{E}-06$ & $\mathrm{Na}$ & 1.17 \\
$\mathrm{Ca}$ & $3.41 \mathrm{E}-02$ & $\mathrm{NO}_{3}$ & 4.46 \\
$\mathrm{Ce}$ & $3.63 \mathrm{E}-04$ & $\mathrm{Ni}^{2}$ & $1.63 \mathrm{E}-03$ \\
$\mathrm{Cl}$ & $3.52 \mathrm{E}-02$ & $\mathrm{~Pb}$ & $9.51 \mathrm{E}-04$ \\
$\mathrm{Cs}$ & $7.52 \mathrm{E}-05$ & $\mathrm{PO}{ }_{4}$ & $<9.18 \mathrm{E}-03$ \\
$\mathrm{Cr}$ & $5.63 \mathrm{E}-03$ & $\mathrm{Sr}$ & $5.15 \mathrm{E}-03$ \\
$\mathrm{~F}$ & $9.66 \mathrm{E}-02$ & $\mathrm{SO}{ }_{4}$ & $3.86 \mathrm{E}-02$ \\
$\mathrm{Fe}$ & $2.40 \mathrm{E}-02$ & $\mathrm{Zr}$ & $3.86 \mathrm{E}-04$ \\
$\mathrm{Hg}$ & $1.80 \mathrm{E}-03$ & $95 \mathrm{Zr}(\mathrm{dps} / \mathrm{mL})$ & 79.7 \\
${ }^{203} \mathrm{Hg}(\mathrm{dps} / \mathrm{mL})$ & 16.3 & ${ }^{241} \mathrm{Am}(\mathrm{dps} / \mathrm{mL})$ & 1,090 \\
\hline
\end{tabular}


Table 8. Comparison of results obtained from flowsheet testing with simulant and actual waste.

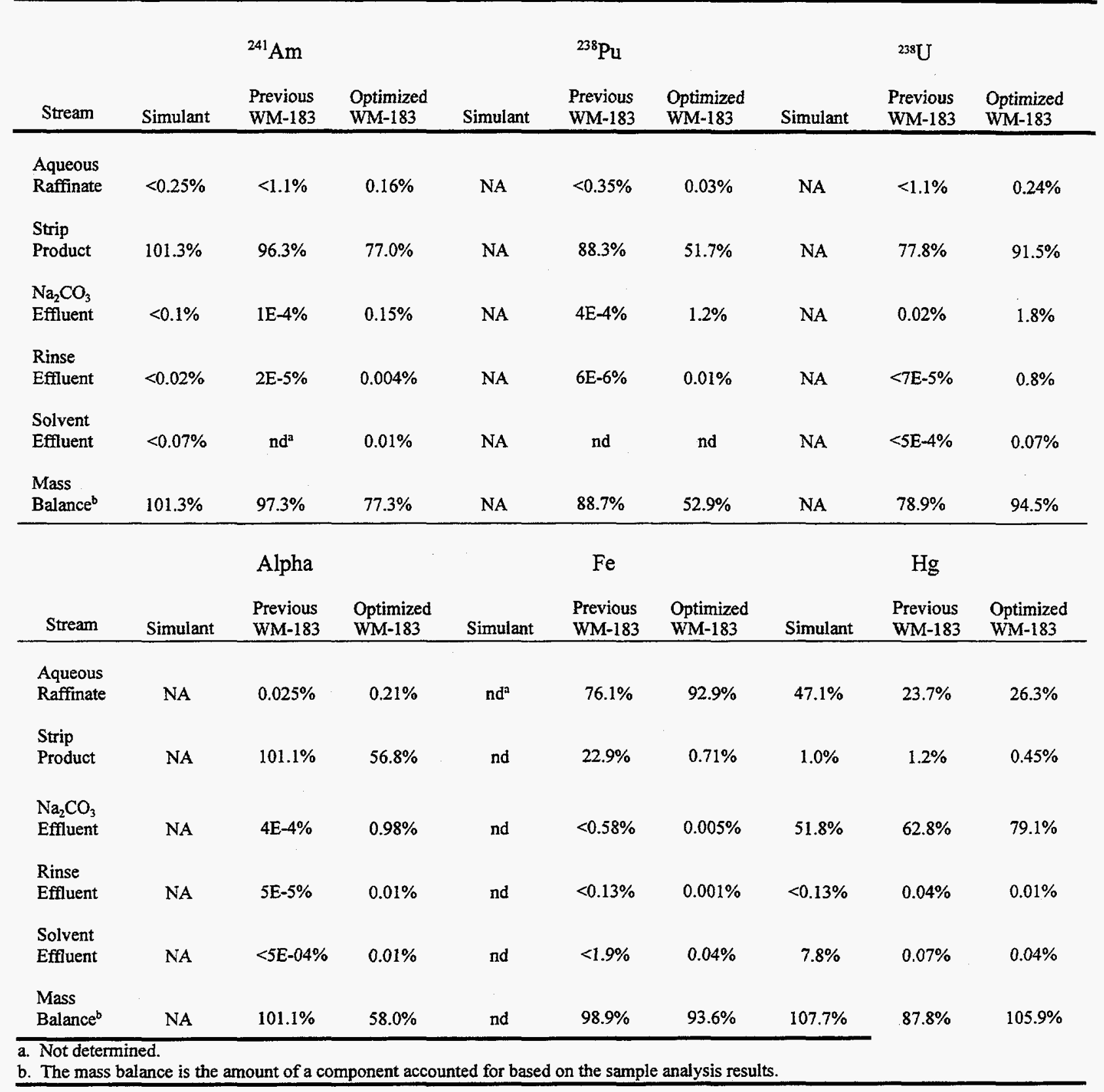




\section{CONCLUSIONS AND RECOMMENDATIONS}

\section{Conclusions}

An overall removal efficiency of $99.79 \%$ was obtained for the actinides. As a result, the activity of the actinides was reduced from $540 \mathrm{nCi} / \mathrm{g}$ in the feed to $0.9 \mathrm{nCi} / \mathrm{g}$ in the aqueous raffinate, which is well below the NRC Class A LLW requirement of $10 \mathrm{nCi} / \mathrm{g}$ for non-TRU waste. Therefore, the use of six extraction stages is adequate for the separation of actinides from SBW. Removal efficiencies of $99.84 \%$, 99.97\%, 99.97\%, 99.76\%, and 99.85\%, were obtained for ${ }^{241} \mathrm{Am},{ }^{238} \mathrm{Pu},{ }^{239} \mathrm{Pu},{ }^{235} \mathrm{U}$, and ${ }^{238} \mathrm{U}$, respectively.

Distribution coefficients were determined for total alpha, ${ }^{241} \mathrm{Am}, \mathrm{Pu}, \mathrm{U}, \mathrm{H}^{+}, \mathrm{Fe}$, and $\mathrm{Hg}$ for most stages (see Tables 5 and 6 ). The distribution coefficients are in good agreement with results obtained from previous flowsheet testing.

The 0.01 $M$ HEDPA strip section was effective in back-extracting the actinides from the TRUEX solvent; however, poor material balances for $\mathrm{Am}$ and $\mathrm{Pu}$ indicate that a precipitate may have formed in the strip section.

Iron was effectively scrubbed from the TRUEX solvent, resulting in only $0.7 \%$ of the Fe exiting in the strip product. Mercury was extracted by the TRUEX solvent (73.7\%) and stripped from the solvent in the $0.25 \mathrm{M} \mathrm{Na}_{2} \mathrm{CO}_{3}$ wash section. Only $0.45 \%$ of the $\mathrm{Hg}$ exited with the high-activity waste strip product.

Steady state was achieved in the strip product and aqueous raffinate within 30 minutes for $\mathrm{H}+$ and within 75 minutes for $\mathrm{Hg}$. Total alpha reached steady state in the strip product within 60 minutes; however, the total alpha activity in the raffinate declined consistently throughout the test. It is postulated that residual activity from previous testing in the contactors and/or tubing was contaminating the raffinate samples. This activity would slowly be flushed out of the equipment, resulting in a decline in alpha activity in the raffinate as the test proceeded.

Flooding or third phase formation was not observed during the flowsheet testing.

Centrifugal contactor flowsheet test results compared well with previous flowsheet testing using WM-183 waste and with previous flowsheet testing using simulated SBW spiked with tracers.

\section{Recommendations}

The flowsheet shown in Figure 2 is effective for the separation of actinides from ICPP sodiumbearing waste; however, a precipitate formed in the strip section. Further studies should be performed to determine flowsheet adjustments to prevent this precipitate formation. 


\section{REFERENCES}

1. A. L Olson, W. W. Schulz, L. A. Burchfield, C. D. Carlson, J. L. Swanson, and M. C. Thompson, Evaluation and Selection of Aqueous Based Technology for Partitioning Radionuclides from ICPP Calcine, WINCO-1071, February 1993.

2. E. P. Horwitz, et. al., Solvent Extr. \& Ion Exch., $\underline{3}(1 \& 2), 75,1985$.

3. E P. Horwitz, M. L. Dietz, and D. E. Fisher, "Extraction of Strontium from Nitric Acid Solutions Using Dicyclohexano-18-Crown-6 and its Derivatives," Sol. Extr. \& Ion Exch., $\underline{8}(4 \& 5), 557-572$, 1990.

4. E. P. Horwitz, M. L. Dietz, and D. E. Fisher, "SREX: A New Process for the Extraction and Recovery of Strontium from Acidic Nuclear Waste Streams," Sol. Extr. \& Ion Exch., 9(1), 1-25, 1991.

5. E. P. Horwitz, M. L. Dietz, and D. E. Fisher, "Extraction of Strontium from Acidic Nitrate Media using a Modified PUREX Solvent," Sol. Extr. \& Ion Exch., 13(1), 1-17, 1995.

6. J. D. Law, K. N. Brewer, R. S. Herbst, and T. A. Todd, Demonstration of the TRUEX Process for Partitioning of Actinides from Actual ICPP Tank Waste Using Centrifugal Contactors, INEL96/0353, September 1996.

7. R. Chiarzia and E. P. Horwitz, Sol. Extr. \& Ion Exch., $\underline{8}(6), 907,1990$.

8. K. N. Brewer, R. S. Herbst, T. J. Tranter, and T. A. Todd, CMPO Purity Tests in the TRUEX Solvent Using Americium-241, WINCO-1177, December 1993.

9. R. S. Herbst, K. N. Brewer, T. J. Tranter, and T. A. Todd, TRUEX Partitioning from Radioactive ICPP Sodium Bearing Waste, INEL-95/0224, March 1995.

10. J. D. Law and R. S. Herbst, TRUEX Flowsheet Development as Applied to ICPP Sodium-Bearing Waste Using Centrifugal Contactors, INEL-95/0130, February 1995.

11. R. S. Herbst, K. N. Brewer, T. J. Tranter, and T. A. Todd, "Mercury Extraction by the TRUEX Process Solvent. I. Kinetics, Extractable Species, and Dependence on Nitric Acid Concentration," Sol. Extr. \& Ion Exch., 13(4), 431-446, 1995. 
Appendix A

\section{Experimental Data}


Table A-1. Approach to steady state samples.

\begin{tabular}{ccccc}
\hline Description & $\begin{array}{c}\text { Sample } \\
\text { Label }\end{array}$ & $\begin{array}{c}\text { Alpha } \\
\text { (dps } / \mathrm{mL})\end{array}$ & $\begin{array}{c}\mathrm{H}+ \\
(M)\end{array}$ & $\begin{array}{c}\mathrm{Hg} \\
(M)\end{array}$ \\
\hline Approach & $1 \mathrm{aq}-30$ & $1.65 \mathrm{E}+02$ & 1.411 & $3.06 \mathrm{E}-04$ \\
To & $1 \mathrm{aq}-60$ & $8.23 \mathrm{E}+01$ & 1.407 & $3.72 \mathrm{E}-04$ \\
Steady & $1 \mathrm{aq}-90$ & $8.23 \mathrm{E}+01$ & 1.401 & $3.97 \mathrm{E}-04$ \\
State & $11 \mathrm{aq}-30$ & $4.07 \mathrm{E}+04$ & 0.121 & $3.22 \mathrm{E}-05$ \\
& $11 \mathrm{aq}-60$ & $3.03 \mathrm{E}+04$ & 0.122 & $2.01 \mathrm{E}-05$ \\
& $11 \mathrm{aq}-90$ & $3.75 \mathrm{E}+04$ & 0.125 & $2.62 \mathrm{E}-05$ \\
\hline
\end{tabular}

Table A-2. Effluent samples taken just prior to shutdown.

\begin{tabular}{|c|c|c|c|c|c|c|c|c|c|c|c|c|c|c|c|}
\hline Description & $\begin{array}{c}\text { Sample } \\
\text { Label }\end{array}$ & $\begin{array}{c}\text { Alpha } \\
\text { (dps/mL) }\end{array}$ & $\begin{array}{c}\text { Am-241 } \\
(\mathrm{dps} / \mathrm{mL})\end{array}$ & $\begin{array}{c}\mathrm{Pu}-238 \\
\text { (dps/mL) }\end{array}$ & $\begin{array}{c}\text { Pu-239 } \\
\text { (dps/mL) }\end{array}$ & $\begin{array}{l}\text { U-235 } \\
(\mathrm{ppm})\end{array}$ & $\begin{array}{l}\text { U-238 } \\
\text { (ppm) }\end{array}$ & $\begin{array}{l}\mathrm{H}+ \\
(M)\end{array}$ & $\begin{array}{l}\mathrm{Fe} \\
(M)\end{array}$ & $\begin{array}{l}\mathrm{Na} \\
(M)\end{array}$ & $\underset{(M)}{\mathbf{K}}$ & $\begin{array}{l}\mathrm{Ca} \\
(M)\end{array}$ & $\begin{array}{l}\mathrm{Al} \\
(M)\end{array}$ & $\begin{array}{l}\mathrm{Pb} \\
(M)\end{array}$ & $\begin{array}{l}\mathrm{Hg} \\
(M)\end{array}$ \\
\hline FEED Sample & WM-183 & $2.49 \mathrm{E}+04$ & $1.61 \mathrm{E}+03$ & $1.49 \mathrm{E}+04$ & $5.58 \mathrm{E}+03$ & $1.29 \mathrm{E}+01$ & $1.10 \mathrm{E}+02$ & $1.80 \mathrm{E}+00$ & $3.00 \mathrm{E}+03$ & $8.05 \mathrm{E}-01$ & $1.06 \mathrm{E}-01$ & $3.77 \mathrm{E}-02$ & $5.78 \mathrm{E}-01$ & $1.08 \mathrm{E}-03$ & $2.34 \mathrm{E}-03$ \\
\hline Product & 1aq-Prod & $4.11 \mathrm{E}+01$ & $2.03 \mathrm{E}+00$ & $3.69 \mathrm{E}+00$ & $1.48 \mathrm{E}+00$ & $1.51 \mathrm{E}-02$ & $2.06 \mathrm{E}-01$ & 1.436 & 2156.300 & $6.13 E-01$ & $1.08 \mathrm{E}-01$ & $2.74 \mathrm{E}-02$ & $4.48 \mathrm{E}-01$ & $1.26 \mathrm{E}-03$ & $4.76 \mathrm{E}-04$ \\
\hline Samples & 11 aq-Prod & $3.40 \mathrm{E}+04$ & $2.98 \mathrm{E}+03$ & $1.85 E+04$ & $6.96 \mathrm{E}+03$ & $2.79 E+01$ & $2.42 \mathrm{E}+02$ & 0.123 & 51.500 & $1.23 \mathrm{E}-03$ & $1.49 \mathrm{E}-04$ & $<2.19 \mathrm{E}-02$ & $<1.55 \mathrm{E}-01$ & $<2.85 \mathrm{E}-04$ & $2.54 \mathrm{E}-05$ \\
\hline Prior & 17aq-Prod & $5.49 \mathrm{E}+02$ & $5.62 E+00$ & $3.92 \mathrm{E}+02$ & $1.47 \mathrm{E}+02$ & $5.30 \mathrm{E}-01$ & $4.57 \mathrm{E}+00$ & & $3.60 \mathrm{E}-01$ & & $7.29 \mathrm{E}-06$ & $<1.20 \mathrm{E}-04$ & $<8.49 \mathrm{E}-04$ & & $4.17 \mathrm{E}-03$ \\
\hline To & 19aq-Prod & $3.56 \mathrm{E}+01$ & $9.10 \mathrm{E}-01$ & $2.09 \mathrm{E}+01$ & $7.96 \mathrm{E}+00$ & $1.42 \mathrm{E}+00$ & $1.10 \mathrm{E}+01$ & & $5.40 \mathrm{E}-01$ & $1.46 \mathrm{E}-03$ & $1.30 \mathrm{E}-05$ & $<1.20 \mathrm{E}-04$ & $<8.49 \mathrm{E}-04$ & & $3.68 \mathrm{E}-06$ \\
\hline Shutdown & 20or-Prod & $3.46 \mathrm{E}+00$ & $4.50 \mathrm{E}-01$ & & & $1.72 \mathrm{E}-02$ & $1.72 \mathrm{E}-01$ & & $2.68 \mathrm{E}+00$ & & & & & $<2.85 \mathrm{E}-04$ & $2.10 \mathrm{E}-06$ \\
\hline
\end{tabular}


Table A-3. Sample data for the individual contactor stages after phase re-equilibration.

\begin{tabular}{|c|c|c|c|c|c|c|c|c|c|}
\hline Description & $\begin{array}{l}\text { Sample } \\
\text { Label }\end{array}$ & $\begin{array}{c}\text { Gross Alpha } \\
\text { (dps/mL) }\end{array}$ & $\begin{array}{c}\text { Am-241 } \\
\text { (dps/mL) }\end{array}$ & $\begin{array}{c}\text { Pu-238 } \\
\text { (dps/mL) }\end{array}$ & $\begin{array}{c}\text { Pu-239 } \\
\text { (dps/mL) }\end{array}$ & $\begin{array}{l}\text { U-238 } \\
\text { (mg/L) } \\
\end{array}$ & $\begin{array}{l}\mathrm{H}+ \\
(M)\end{array}$ & $\begin{array}{c}\mathrm{Fe} \\
(\mathrm{ppm})\end{array}$ & $\begin{array}{c}\mathrm{Hg} \\
(\mathrm{ppm})\end{array}$ \\
\hline \multirow[t]{12}{*}{ Extraction } & lor & & $4.11 \mathrm{E}+00$ & $2.25 \mathrm{E}+01$ & $5.41 E+01$ & $8.57 \mathrm{E}+00$ & & & \\
\hline & $1 \mathrm{aq}$ & $8.24 E+00$ & & & & $5.76 \mathrm{E}-01$ & 1.455 & $1.96 \mathrm{E} \div 03$ & $6.77 \mathrm{E}+01$ \\
\hline & 2 or & & $8.40 \mathrm{E}+00$ & $1.12 E+01$ & $6.94 \mathrm{E}+01$ & $6.92 \mathrm{E}+00$ & & & \\
\hline & $2 \mathrm{aq}$ & $2.46 \mathrm{E}+01$ & & & & $5.10 \mathrm{E}-01$ & 1.768 & $2.00 \mathrm{E}+03$ & $1.24 \mathrm{E}+02$ \\
\hline & 3 or & & $1.15 \mathrm{E}+01$ & $1.72 \mathrm{E}+01$ & $8.60 \mathrm{E}+01$ & $7.07 \mathrm{E}+00$ & & $1.45 \mathrm{E}+03$ & \\
\hline & $3 \mathrm{aq}$ & $2.88 \mathrm{E}+01$ & & & & $5.00 \mathrm{E}-01$ & 1.802 & $1.85 \mathrm{E}+03$ & $2.53 \mathrm{E}+02$ \\
\hline & 4or & & $4.19 \mathrm{E}+01$ & $1.80 \mathrm{E}+01$ & $1.25 E+02$ & $7.08 \mathrm{E}+00$ & & $1.62 \mathrm{E}+03$ & \\
\hline & $4 a q$ & $2.46 \mathrm{E}+01$ & $2.19 \mathrm{E}+00$ & & & $5.34 \mathrm{E}-01$ & 1.801 & $2.20 \mathrm{E}+03$ & $2.83 E+02$ \\
\hline & 5or & $5.10 \mathrm{E}+02$ & $3.62 \mathrm{E}+02$ & $2.00 \mathrm{E}+02$ & $1.09 \mathrm{E}+03$ & $3.39 \mathrm{E}+01$ & & $3.68 \mathrm{E}+02$ & \\
\hline & $5 \mathrm{aq}$ & $5.75 \mathrm{E}+01$ & $1.16 \mathrm{E}+01$ & & & $7.25 \mathrm{E}-01$ & 1.819 & $1.96 \mathrm{E}+03$ & $3.60 \mathrm{E}+02$ \\
\hline & 6or & & & & & & & & \\
\hline & $6 a q$ & $9.86 \mathrm{E}+01$ & $7.22 \mathrm{E}+01$ & $2.87 \mathrm{E}+00$ & & $1.50 \mathrm{E} \div 00$ & 1.822 & $1.97 \mathrm{E}+03$ & $3.92 \mathrm{E}+02$ \\
\hline \multirow[t]{8}{*}{ Scrub } & 7 or & $5.76 \mathrm{E}+04$ & $1.68 \mathrm{E}+05$ & $3.03 \mathrm{E}+04$ & $1.24 \mathrm{E}+04$ & $7.52 \mathrm{E}+02$ & & & \\
\hline & $7 \mathrm{aq}$ & $2.22 \mathrm{E}+02$ & $1.57 \mathrm{E}+02$ & $3.05 \mathrm{E}+00$ & & $7.18 \mathrm{E}-01$ & 1.622 & 1.37E+03 & $2.19 \mathrm{E}+02$ \\
\hline & 8 or & $1.24 \mathrm{E}+04$ & $7.53 \mathrm{E}+02$ & $6.61 \mathrm{E}+03$ & $2.68 \mathrm{E}+03$ & $1.50 \mathrm{E} \div 02$ & & & \\
\hline & $8 a q$ & & & & & $1.39 \mathrm{E}+00$ & 0.868 & $4.25 \mathrm{E}+01$ & $4.47 E+00$ \\
\hline & $90 r$ & $1.24 \mathrm{E} \div 04$ & $9.52 \mathrm{E}+02$ & $6.96 \mathrm{E}+03$ & $2.50 \mathrm{E} \div 03$ & $2.80 \mathrm{E}+02$ & & & \\
\hline & $9 \mathrm{aq}$ & $3.74 \mathrm{E}+02$ & $3.70 \mathrm{E}+02$ & $5.90 \mathrm{E}+00$ & $2.51 \mathrm{E}+00$ & $1.30 \mathrm{E}+00$ & & $3.01 E+02$ & $2.03 \mathrm{E}+01$ \\
\hline & $10 \mathrm{or}$ & $7.17 \mathrm{E}+04$ & $4.98 \mathrm{E} \div 03$ & $4.16 \mathrm{E}+04$ & $2.15 \mathrm{E}+04$ & $3.82 \mathrm{E}+02$ & & $1.66 \mathrm{E}+02$ & \\
\hline & $10 \mathrm{aq}$ & $7.15 \mathrm{E}+02$ & $7.11 \mathrm{E}+02$ & $1.38 \mathrm{E}+01$ & $4.80 \mathrm{E}+00$ & $1.65 \mathrm{E}+00$ & 0.309 & $9.66 \mathrm{E}+01$ & $2.01 E \div 01$ \\
\hline \multirow[t]{12}{*}{ Strip } & $110 r$ & $1.91 \mathrm{E}+04$ & $1.84 \mathrm{E}+03$ & $1.04 \mathrm{E}+04$ & $5.25 \mathrm{E}+03$ & $3.43 \mathrm{E}+02$ & & $1.09 \mathrm{E}+02$ & \\
\hline & $11 \mathrm{aq}$ & $3.34 \mathrm{E} \div 04$ & $3.26 \mathrm{E} \div 03$ & $2.16 \mathrm{E}+04$ & $8.04 \mathrm{E}+03$ & $2.16 \mathrm{E}+02$ & 0.146 & $2.99 \mathrm{E}+01$ & $2.09 \mathrm{E}+01$ \\
\hline & $120 r$ & $1.29 \mathrm{E}+03$ & $6.37 \mathrm{E}+01$ & $1.30 \mathrm{E} \div 03$ & $5.12 E+03$ & $1.87 \mathrm{E}+01$ & & $1.56 \mathrm{E}+02$ & \\
\hline & $12 \mathrm{aq}$ & $5.72 \mathrm{E}+03$ & $1.91 \mathrm{E}+02$ & $3.74 \mathrm{E}+03$ & $1.35 \mathrm{E}+03$ & $1.04 \mathrm{E}+02$ & 0.049 & & $2.45 \mathrm{E}+00$ \\
\hline & 13 or & $1.20 \mathrm{E}+03$ & $1.95 \mathrm{E}+01$ & $8.19 \mathrm{E}+02$ & $3.51 E+02$ & $1.97 \mathrm{E}+01$ & & $1.37 \mathrm{E}+02$ & \\
\hline & $13 \mathrm{aq}$ & $2.20 \mathrm{E}+03$ & $1.47 \mathrm{E}+01$ & $1.50 \mathrm{E}+03$ & $5.62 \mathrm{E}+02$ & $2.48 \mathrm{E}+01$ & & $1.67 \mathrm{E}+00$ & $4.88 \mathrm{E}+00$ \\
\hline & $140 r$ & $9.72 \mathrm{E}+02$ & $5.28 \mathrm{E} \div 00$ & $5.43 E+02$ & $2.34 E+02$ & $2.70 E+00$ & & $2.40 \mathrm{E}+00$ & \\
\hline & $14 a q$ & $1.21 \mathrm{E}+03$ & $1.05 \mathrm{E}+01$ & $6.05 \mathrm{E}+02$ & $2.28 \mathrm{E}+02$ & $1.05 \mathrm{E}+01$ & & $1.13 \mathrm{E}+00$ & $9.04 \mathrm{E}-01$ \\
\hline & 15 or & & & & & & & & \\
\hline & $15 \mathrm{aq}$ & $6.52 E+02$ & $8.35 \mathrm{E}+00$ & $4.48 \mathrm{E}+02$ & $1.67 \mathrm{E}+02$ & $7.09 \mathrm{E}+00$ & & $1.65 E+00$ & $7.65 \mathrm{E}-01$ \\
\hline & $160 r$ & $4.23 \mathrm{E}+02$ & $2.12 \mathrm{E}+00$ & $6.31 E+01$ & $7.68 \mathrm{E}+01$ & $3.12 \mathrm{E}+00$ & & $5.50 \mathrm{E}+00$ & \\
\hline & $16 \mathrm{aq}$ & $2.62 \mathrm{E}+02$ & $5.01 \mathrm{E}+00$ & $1.84 \mathrm{E}+02$ & $6.88 \mathrm{E}+01$ & $4.01 \mathrm{E}+00$ & & $7.10 \mathrm{E}-01$ & $7.55 \mathrm{E}-01$ \\
\hline $\mathrm{Na}_{2} \mathrm{CO} 3$ & 17 or & $3.77 \mathrm{E}+01$ & $2.29 \mathrm{E}+00$ & $3.53 \mathrm{E}+01$ & $1.91 \mathrm{E}+01$ & $4.85 \mathrm{E}-01$ & & $2.45 E+00$ & \\
\hline \multirow[t]{3}{*}{ Wash } & $17 \mathrm{aq}$ & $4.80 \mathrm{E}+02$ & $2.86 \mathrm{E}+00$ & $2.61 \mathrm{E}+02$ & $9.70 \mathrm{E}+01$ & $3.81 \mathrm{E}+00$ & & $3.60 \mathrm{E}-01$ & $8.36 \mathrm{E} \div 02$ \\
\hline & $180 \mathrm{r}$ & $2.76 \mathrm{E}+01$ & $6.10 \mathrm{E}-01$ & $1.13 \mathrm{E}+01$ & $5.60 \mathrm{E}+00$ & $5.77 \mathrm{E}-01$ & & $2.12 \mathrm{E}+00$ & \\
\hline & $18 \mathrm{aq}$ & $8.07 E+01$ & $9.70 \mathrm{E}-01$ & $5.80 \mathrm{E}+01$ & $2.19 \mathrm{E}+01$ & $2.51 \mathrm{E}-01$ & & $6.64 \mathrm{E}+00$ & $2.00 \mathrm{E}-01$ \\
\hline Acid & $190 r$ & $3.18 \mathrm{E}+01$ & $7.02 \mathrm{E}-01$ & $2.69 \mathrm{E}+01$ & $1.06 \mathrm{E}+01$ & $7.17 \mathrm{E}-01$ & & $2.39 \mathrm{E}+00$ & \\
\hline \multirow[t]{3}{*}{ Rinse } & $19 \mathrm{aq}$ & $8.30 E+00$ & $1.44 \mathrm{E}+00$ & $2.86 \mathrm{E}+00$ & $8.70 \mathrm{E}-01$ & $1.00 \mathrm{E}-02$ & & $5.44 \mathrm{E}-01$ & 7.39E-0I \\
\hline & $20 \mathrm{or}$ & $1.37 \mathrm{E}+01$ & $5.00 \mathrm{E}-01$ & $1.13 \mathrm{E}+01$ & $4.50 \mathrm{E}+00$ & $1.07 E+00$ & & $2.68 \mathrm{E}+00$ & \\
\hline & $20 \mathrm{aq}$ & $2.10 \mathrm{E}+00$ & $3.77 \mathrm{E}-01$ & $1.42 E \div 00$ & $6.40 \mathrm{E}-01$ & $<1.20 \mathrm{E}-03$ & & & $9.61 \mathrm{E}-01$ \\
\hline
\end{tabular}

